\title{
Stem Cell Therapies for Ischemic Cardiovascular Diseases
}

\author{
Colin E. Murdoch ${ }^{1, *}$, Sophie A. Broadway-Stringer ${ }^{1}$, Milda Bartkeviciute ${ }^{1}$, Camilla Siciliano ${ }^{2,3}$, \\ Roberta Altobelli ${ }^{2}$ and Elena De Falco,**
}

\author{
${ }^{1}$ Reproductive and Vascular Biology Division, Aston Medical School, Aston University, Birmingham, B4 7ET, UK; \\ ${ }^{2}$ Faculty of Pharmacy and Medicine, Department of Medical-Surgical Science and Biotechnologies, University of Rome \\ "Sapienza" C.so della Repubblica 79, 04100 Latina, Italy; ${ }^{3}$ Center for Life Nano Science@Sapienza, Istituto Italiano di \\ Tecnologia, Rome, Italy
}

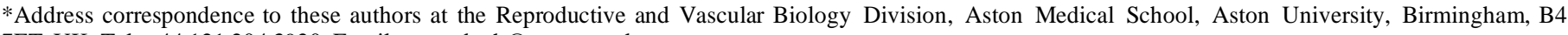
7ET, UK; Tel: +44 121204 3920; Email: c.murdoch@aston.ac.uk

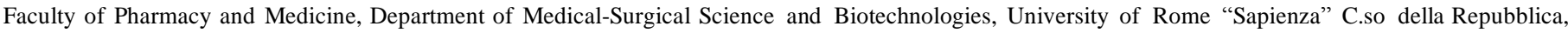
79, 04100, Latina, Italy; Tel: +39-0773-1757234; Fax: +39-

0773-1757254; E-mail: elena.defalco@uniroma1.it
\end{abstract}

\begin{abstract}
Myocardial infarction results in loss of cardiac muscle and deficiency in cardiac performance. Likewise, peripheral artery disease can result in critical limb ischemia leading to reduced mobility, non-healing ulcers, gangrene and amputation. Both of these common conditions diminish quality of life and enhance risk of mortality. Successful advances in treatment have led to more people surviving incidences of myocardial infarction or living with peripheral artery disease. However, the current treatments are inadequate in repairing ischemic tissue. Over the last 5 years, a vast number of patents have been submitted concerning the use of stem cells, which correlates with the exponential growth in stem cell publications. Exploiting stem cell therapy offers a real potential in replacing ischemic tissue with functional cells. In this paper, we review recent patents concerning stem cell therapy that have the potential to provide or potentiate novel treatment for ischemic cardiovascular disease. In addition, we evaluate the promise of the inventions by describing some clinical trials that are currently taking place, as well as considering how current research on ischemic cardiovascular disease may change the patent landscape in the future.
\end{abstract}

Keywords: Cardiovascular, cell therapy, heart, ischemia, regenerative medicine, stem cells.

\section{INTRODUCTION}

The use of cultured cells in tissue repair dates back to the beginning of the $20^{\text {th }}$ century [1]. The huge potential for stem cells to deliver cell-driven repair arises from their distinct properties that include immunological tolerance as an allo-

genic transplant, potential to develop into multiple lineages and relative ease of harvesting and expansion. These proper- ties initiated a great determination to understand how stem cells can be fully utilized in a wide range of diseases. The 90's saw a great burst in publications on stem cells which has been growing exponentially ever since Fig. (1a) [2]. Research in stem cells has driven the unmistakable confidence, ability and ambition in regenerative medicine, which is reflected in the number of patent submissions claiming unique intellectual property within this field. Since 1990 there has been approxi- mately 5500 patents regarding stem cells, remarkably half of these have been submitted in the last 5 years Fig. (1b) [2]. We have focused this review on how stem cell technology would benefit ischemia cardiovascular disease of the heart (myocar- dial infarction (MI)) and lower limb (peripheral artery disease (PAD)). We have highlighted how stem cell technologycan be utilized and document recent submitted patents and current clinical trials associated with these diseases.

\section{MYOCARDIAL INFARCTION}

The European Society of Cardiology estimated that car- diovascular disease is responsible for 1.9 million deaths each year in the EU, which equates to $40 \%$ of all deaths within the EU. In the UK, it is projected that there are 103,000 MIs each year [3], with similar numbers found in most other European countries. The survival rate of people who suffer a heart attack is increasing as a result of better knowledge and treatment of the disease. Subsequently, more patients are now living with their heart in a compromised state [3]. In the post-infarcted heart, a large area of the myocardium remains non-functional as a result of ischemia, causing remodeling of the non-infarcted region and fibrosis, triggering abnormal filling, pumping and electrical signaling of the heart. Current treatment with therapy only treats the symptoms but does not tackle the primary issue of loss of cardiac tissue. Repair of the ischemic heart using a pool of easily sourced human cells is the holy grail of cardiovascular medicine and would in- crease the long term survival rate and quality of life of peo- ple who have suffered from a myocardial infarction [1].

\section{PERIPHERAL ARTERY DISEASE}

PAD affects an estimated 27 million people across Northern America and Europe [4, 5]. PAD is caused by 
A

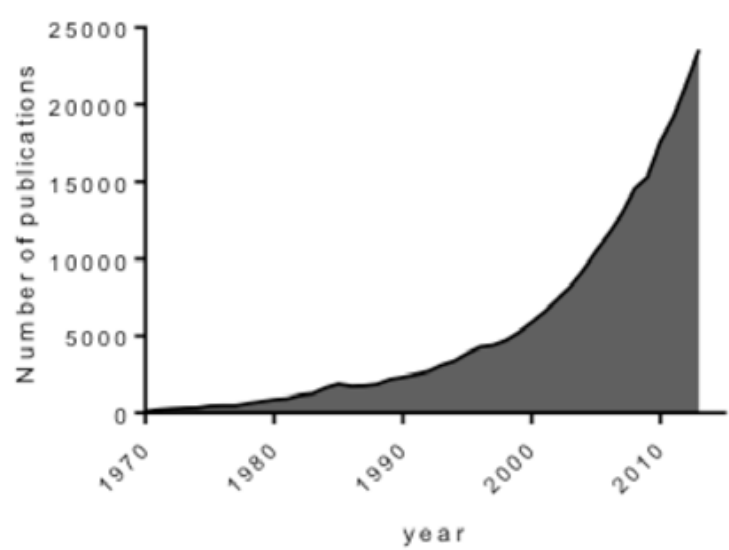

B

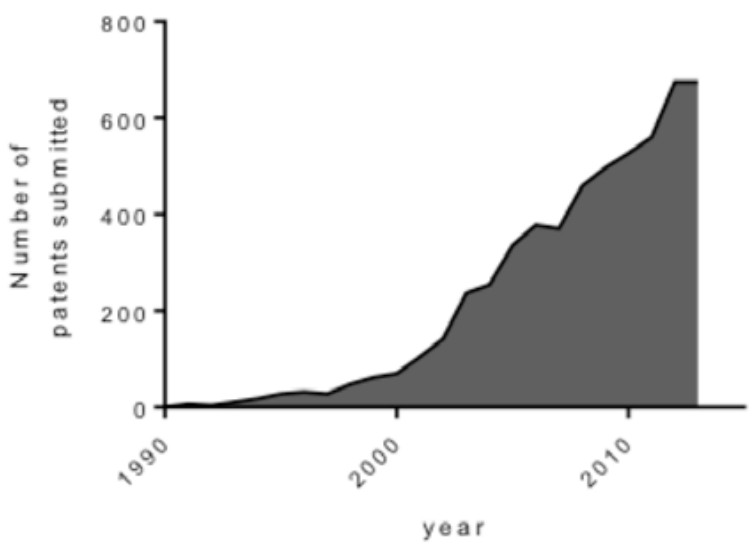

Fig. (1). Number of publications and patents submitted relating to stem cell corresponding to their publication year. Fig. (1a), number of publications regarding "stem cell" returned corresponding to the publication year using NCBI biomedical search site (pubmed.gov [77]). Fig. (1b); number of patents submitted worldwide over the corresponding years searched using Espacenet worldwide patent search (www.epo.org) [2].

atherosclerosis in the lower extremities or abdomen, usually presented clinically as intermittent claudication [5]. Patients are initially faced with worsening burden from chronic pain whilst walking, to non-healing ulcers, gangrene and finally potential limb loss [6]. Increased risk of other cardiovascular diseases (CVD) events are high for instance PAD is the third leading cause of atherosclerotic cardiovascular morbidity. As

7-8\% of the population in Europe [4] is predicted to suffer from PAD, this has a significant consequence on the econ- omy and health care systems [6]. Restoring perfusion in PAD patients to improve blood flow to the ischemic tissue would alleviate the pain and also offer the best possible chance of preventing amputation. Stem cells have the ability to promote collateral vessel growth, which would achieve the aspired therapeutic angiogenesis [7].

\section{SOURCES OF STEM CELL}

A number of stem cell and progenitor cell populations have the potential to be employed to aid cardiac repair or relieve peripheral ischemia. There are disadvantages and advantages for each cell type and some such as embryonic stem cells have further ethical limitations to overcome. The health status of the donor patient has a great impact on the number and effectiveness of stem cells [8]. We briefly de- scribe some of the sources of stem cells.

Endothelial Progenitor Cells (EPCs) have been defined to express CD133+, CD34+ and vascular endothelial growth factor receptor-2 [9]. EPCs have been suggested to potentially bolster neovascularization by differentiating into endothelial cells at the site of ischemia. Isolation of EPC cells were found to mostly contain a mononuclear cell $\left(\mathrm{CD} 14^{+} / \mathrm{CD} 34^{+}\right)$subpopulation, interestingly these cell have the potential to aid angiogenesis through release of paracrine factors [10]. There is controversy in use of EPCs in stem cell research as EPC characterization, isolation, and mechanism of action are far from being fully understood and standardized. In addition, elderly, diabetics and patients with cardiovascular disease all 
have low EPC numbers [11]; moreover the angiogenic capac- ity of their EPCs is significantly reduced thus limiting the therapeutic usefulness.

CD133+ Cells. Early hematopoietic stem cells (HSCs) and EPCs both express the cell surface antigen CD133 and both synergistically enhance vascularization of ischemic tissues by differentiating into endothelial cells at the site of ischemia. CD133+ cells numbers are severely limited for therapeutic value, very small proportion (approximately 1\%) of bone marrow cells (BMCs) are CD133+. Furthermore CD133+ cells can't be expanded ex vivo [12].

Mesenchvmal Stem Cells (MSCs) are routinely isolated from bone marrow, selected and expanded in culture. MSCs have the potential in theory to differentiate into any of the mesodermal linage which includes smooth, skeletal and car- diac muscle. However, the ability of MSCs to differentiate into cardiomyocytes is rare in vivo. MSCs may have a posi- tive paracrine effect by secreting anti-inflammatory, anti- apoptotic and pro-angiogenic factors [13].

Resident Stem Cells A pool of resident cardiac progenitor cells (CPCs) have been identified in the heart that can differ- entiate into new cardiomyocytes [14], endothelial cells or smooth muscle cells [12], thus changing the textbook-concept of the terminally differentiated heart. CPC population com- prises of cardiosphere-dervived cells (CDCs), cardiomyocyte progenitor cells (CMPCs) and c-kit+ cardiac stem cell (CSCs) [15]. CPCs have the potential advantage of fully replacing damaged myocardium. However, the disadvantages of using CPCs include low yield, specialist requirement to obtain car- diac biopsy and slow amplification [16].

Vascular Resident_Stem_Cells. Similar to the heart, all three layers of the vasculature (intima, media and adventitia) contain a pool of resident progenitor cell populations which include EPCs, MSCs, CD34+ and Sca-1+ [17, 18] Likewise, these cells have the potential to enhance neovascularization.

Bone Marrow Mononuclear Cells (BMMSCs) are popular candidates for cell based therapy owing to their rela- 

tively ease and amplitude of harvesting under GMP condi- tions. Moreover, BMMNCs comprise of HSCs, MSCs and EPCs, therefore ensure the synergetic advantages of various stem cell populations. BMMNCs have the potential ability to differentiate into cardiac or endothelial cell types, providing paracrine signals [16].

Embryonic Stem Cells (ESCs) are totipotent stem cells harvested from the inner cell mass of blastocysts (4-5 days post fertilization). ESCs have the immense potential to dif- ferentiate into derivatives of all the three cell types ectoderm, endoderm and mesoderm, provide a possible source for car- diomyocytes or endothelial cells. Importantly, human ES cell-derived cardiomyocytes are able to couple electrically with the host myocardium as well as displaying similar struc- tural and functional properties. The major obstacles are the ethical issues related to the use and destruction of human embryos. Nevertheless, clinical trials in the US on hESC have been approved for treating spinal cord injury and macu- lar degeneration [19].

Induced Pluripotent Stem Cells (iPSCs) may hold the key to bypassing ethical issues in ESCs [10]. This technol- ogy reprograms adult differentiated cells to pluripotency, matching the potential and capability of ESCs. Some of the major limitations of iPSC technology include efficacy of generation rates and potential for mutation [20].

\section{PRE-CLINICAL STEM CELLS THERAPY TO TREAT MYOCARDIAL INFARCTION}

In an early study, by Orlic et al. HSCs were injected into the infarct boarder zone in mice subjected to coronary artery ligation [21]. Newly formed HSC-derived myocytes were observed that had replaced the infarcted area and importantly vascular structures were evident. There is controversy in the field regarding these experiments, debating whether the HSC injection actually replaced cardiomyocytes directly or via an indirect method such as paracrine signaling or stimulating an endogenous cardiomyocyte progenitor cell pool [12]. Never- theless, it is clear that cardiac function is enhanced through HSC injection. Indeed some studies have shown that condi- tioned media from human MSC can improve cardiac func- tion post-MI [22].

More recent studies have shown that human CPCs are able to survive and differentiate into cardiac cell types after injection into the border-zone minutes after infarction in murine hearts. Most promising, CPCs had a positive impact left ventricle (LV) function, infarct size, vascularization and fibrosis [23].

A more realistic timeline for clinical application whereby administration of CPCs occurred several months post-MI, still resulted in positive effects on LV function [24]. Trans- plantation of clinical scale human ES-derived cardiomyo- cytes that had been successfully cryopreserved was recently investigated. Administration of human ESC-derived cardio- myocytes were effectively engrafted to the myocardium in a non-human primate model of myocardial infarction [19]. Crucially, these were able to provide substantial new cardiac 
muscle, that had regular calcium transients and synchronized electrocardiograms, and vascularization of the graft from host vessels [19]. Scaling up the cryopreservation of hESC-derived cardiomyocytes promises a fast and effective methodology that could be widely utilized in medical centers that lack stem cell expertise. Such is the promise of this technology clinical trials have been raced through without complete understanding of the exact mechanism [12]. Small trials with a vast range of different conditions have taken place, not all of which have been positive. However, taken together with the growing ex- perimental evidence from in vivo models stem cell therapy is still a viable method to treat MI [25]. Studies are now investi- gating ways in which the survival of the transplanted stem cell population can be enhanced in the myocardium. Currently, early pre-clinical in vivo models provide information on po- tential future patents. Inhibition of the Renin pathway [26] protection by enhancement of the pro-angiogenic receptor Notch 1 [27], and overexpression of myocardin, a transcrip- tion co-activator [28] are all approaches adapting the host en- vironment to potentiate the effect of the stem cells. Other tac- tics consider modifying the progenitor cells themselves. Inhibition of HDAC4, involved in transcription regulation [29] or inositol hexakisphosphate kinases (IP6Ks) to enhance AKT [30] are two current trends published this year.

\section{PRE-CLINICAL STEM CELL THERAPY TO TREAT PAD}

Over 15 years ago, isolation of endothelial progenitor cells (CD34+) from human peripheral blood was described to differentiate into endothelial cells and incorporate into the vasculature of the experimental ischemic limb [31]. Shortly afterwards, Hamano et al. demonstrated that bone marrow injected into the ischemic muscle could induce angiogenesis promoting blood flow recovery in rodent ischemic model via elevated bFGF, IL-1f3 levels and possible stem cell incorpo- ration [32].

Over the preceding years studies have taken place to at- tempt to improve the effectiveness of stem cell therapy in the ischemic limb, these include ways to initiate resident stem cell populations, modify exogenous stem cells, or change the host environment. MSCs can release cytokines such as VEGF and bFGF to promote recovery [33]. Mobilization of resident hematopoietic stem cell niche by combined treat- ment of G-CSF and parathyroid hormone (PTH) improved blood flow recovery in hindlimb ischemia [34]. A similar beneficial effect of PTH was observed in MI model [35]. Combination of mural and endothelial cells derived from ES cells provided an alternative method of enhancing the thera- peutic benefit. Endothelial and mural cell differentiated from embryonic cells-positive for VEGFR2 and were incorporated into the host vasculature as endothelial cells and mural cells improving vessel integrity thus benefiting recovery of the ischemic hindlimb [36]. Alternatively, priming hMSCs to induce VEGF and HGF secretion potentiated stem cell therapeutic effectiveness [37].

An encouraging development for PAD treatment is the use of CTX0E03 a clinical grade human neural stem cell line, which has been previously shown to be beneficial in pre-clinical stroke models by promoting neurogenesis and angiogenesis [38]. Dose dependent improvements in blood flow recovery was observed in mouse model of PAD (hind limb ischemia), suggesting that CTX0E03 may have wider benefits than treatment of stroke [39]. Patents for use of CTX0E03 in treating PAD have been submitted and a clini- cal trial is underway both of which will be discussed later.

Another example of how the host microenvironment can be altered to enhance the effectiveness of BMC therapy is through cotreatment with antioxidants to reduce oxidative stress, inflammatory cell infiltration in the ischemic limb as well as enhancing plasma NO bioavailability [40].

\section{OXIDATIVE STRESS}

Oxidative stress is a hallmark of cardiovascular diseases, strong correlations have been found in MI, PAD, stroke, atherosclerosis, LV hypertrophy, intermittent claudication, critical limb ischemia, and insulin resistance [41, 42].

Oxidative stress involves the generation of reactive oxy- gen or nitrogen species (ROS/RNS), for example superoxide, peroxides, hydrogen peroxide and peroxynitrite to name a few. High levels of ROS/RNS have long-term detrimental effects on cellular function under pathological conditions, but are also recognized as pivotal to cellular signaling in physiological pathways [43]. ROS/RNS can regulate cellular signaling through oxidative post-translation modification of cysteine residues on key proteins. The distinct properties of cysteine residues allow a range of reversible or irreversible oxPTMs, which are largely dependent upon the level of ROS/RNS or antioxidants. Thus, cysteine residues act as sensors detecting ROS/RNS levels providing a mechanistic switch to control protein function [44]. There are a number of antioxidant pathways within the cell to balance the cellu- lar and microenvironments (redox state) such as superoxide dismutase, catalase, glutathione peroxidase, peroxiredoxins, and sulfiredoxin [44].

Of interest to this review, oxidative stress can perturb tissue homeostasis by damaging stem and progenitor cells, leading to aberrant cell proliferation and anomalous differen- tiation patterns in the affected tissue [45].

ROS levels correlate with stem cells (SCs) differentiation capability. High ROS levels are associated with greater differ- entiation of SC, whereas low ROS levels are thought to be protective towards SC by maintaining them in a quiescent state [46]. Comparison of mature endothelial Cells (ECs) with EPCs suggests that EPCs have lower ROS levels as a result of higher antioxidant (MnSOD, catalase and glutathione peroxi- dase) expression. Low ROS levels are thought to preserve EPCs undifferentiated and self-renewing properties essential for EPCs ability to aid in treatment of disease. Whereas, cyto- kine stimulation (e.g. G-CSF) of HSC mobilization into the circulation is mediated via ROS signaling [47]. Redox signal- ing plays an important role in modulating SC function, upset- ting of the redox homeostatsis outside a narrow window may be detrimental to SC function [48]. Exploiting the fine tuning through regulation of antioxidant and ROS generating en- zymes may provide a therapeutic advantage to aid stem cell therapy. 


\section{ENHANCING RETENTION OF STEM CELLS}

Crucial to successful stem cell therapy is the strategy for cell delivery. Adequate numbers are needed to be supplied to the organ and these numbers need to be retained. Delivery approaches to the heart are more complicated than peripheral muscle. Intravenous MSC therapy is the easiest and most practical, however a major drawback are stem cells becom- ing confined in the pulmonary circulation [49]. Transendo- cardial injection provides a low invasive method of stem cell delivery. Stem Cells are directly delivered to the infarcted region using a catheter guided by fluoroscopic guidance or electroanatomic mapping [50]. Cardiac perforation or ar- rhythmias are risk factors that require managing. In contrast, direct intramyocardial injection allow direct visualization of the infarcted myocardium, and perforation can be controlled [51]. However, this method is highly invasive requiring a thoracotomy or sternotomy. Intracoronary infusion of stem cells using a standard over-the-wire balloon angioplasty al- lows a brief period facilitating stem cell retention in the myocardium while the balloon is inflated to stop blood flow [50]. Although, reduced blood flow in the ischemic muscle may prevent effective stem cell delivery; in addition inflation of catheter-balloon may cause further ischemia. However, angioplasty techniques are common procedures for cardiolo- gists, in addition these techniques are now used as front line methods in rapid treatment for acute MI upon presentation in emergency rooms. Therefore, this method of delivery could be dovetailed into current treatment strategies.

The local microenvironment is pivotal to the cell reten- tion as this can impact on cell adhesion, migration and stem cell survival [12]. Co-administration or priming the muscle prior to stem cell delivery could modify the microenviron- ment to a more favorable status for stem cell function. Alter- natively, genetic manipulation or pharmacological treatment of the stem cells may also have beneficial effects. BM-MSCs were genetically modified to express the anti-apoptotic and anti-inflammatory enzyme, heme oxygenase-1 (HO-1). Im- proved cardiac function was observed in a swine MI model 3 months after treatment with HO-1 transfected-MSCs [52].

\section{PATENTS AND PUBLICATIONS}

Some of the recent patents that have submitted to utilize stem cells for the treatment or that can benefit patients with MI or PAD are reviewed below and further summarized in Table 1. The expected therapeutic aims of the patents are to improve retention of stem cells to the site of ischemia, stabi- lization, efficacy by synergistic mechanism such as paracrine secretion.

\section{STEM CELL- BASED THERAPY}

The patent WO2013126590 [53] describes the use of a cell population comprising of CD34+ stem cells isolated

Table 1. Patents Submitted for Treatment of Myocardial Ischemia or Peripheral Artery Disease by Stem Cell Therapy

\begin{tabular}{|c|c|c|c|c|}
\hline $\begin{array}{c}\text { Patent Number } \\
\text { [Reference] }\end{array}$ & Title & Inventors/Assignees & $\begin{array}{l}\text { Published } \\
\text { Date }\end{array}$ & Description \\
\hline \multicolumn{5}{|c|}{ Stem cell } \\
\hline $\begin{array}{l}\text { WO2013126590 } \\
{[53]}\end{array}$ & $\begin{array}{l}\text { Pharmaceutical composition } \\
\text { comprising CD } 34+\text { cells }\end{array}$ & $\begin{array}{l}\text { Palmer, L., Motlagh, D., Cohen, } \\
\text { A., Amrani, D.L. }\end{array}$ & 2013 & $\begin{array}{l}\text { Treatment of ischemic conditions and } \\
\text { diseases using a cell population compris- } \\
\text { ing CD34+ cells isolated from peripheral } \\
\text { blood of a subject }\end{array}$ \\
\hline $\begin{array}{l}\text { US20040258670 } \\
\text { [54] }\end{array}$ & $\begin{array}{l}\text { Introducing enriched human } \\
\text { endothelial generating cells and } \\
\text { mesenchymal stem cells; en- } \\
\text { hancing vasculogenesis and } \\
\text { collateralization around blocked } \\
\text { and/or narrowed vessels }\end{array}$ & Mary, L., Stephen, H., Vincent, P. & 2004 & $\begin{array}{l}\text { Administration of endothelial precursor or } \\
\text { Mesenchymal stem cells enriched for } \\
\text { CD133+/CD34+ cells to improve vascu- } \\
\text { larization in the preferred setting of } \\
\text { ischemic myocardium. }\end{array}$ \\
\hline $\begin{array}{c}\text { EP2 } 428563 \\
{[55]}\end{array}$ & $\begin{array}{c}\text { Vascular/lymphatic endothelial } \\
\text { cells }\end{array}$ & $\begin{array}{l}\text { Prosper, F., Verfaillie, C.M., } \\
\text { Lopez-Aranguren, X., Claver, } \\
\text { C.C., Luttun, A. }\end{array}$ & 2012 & $\begin{array}{l}\text { Method to differentiate cells into more } \\
\text { than one embryonic lineage }\end{array}$ \\
\hline $\begin{array}{l}\text { WO2014022373 } \\
{[56]}\end{array}$ & $\begin{array}{l}\text { Treatment of pulmonary arterial } \\
\text { hypertension with mesenchy- } \\
\text { mal stem cells }\end{array}$ & $\begin{array}{c}\text { Jeffs, R., Petersen, T., Ilagan, } \\
\text { R.M., Wade, M. }\end{array}$ & 2014 & $\begin{array}{l}\text { Method for treating or preventing vascu- } \\
\text { lopathy administrating pharmaceutical } \\
\text { composition comprising mesenchymal } \\
\text { precursor cells }\end{array}$ \\
\hline $\begin{array}{l}\text { US20110250182 } \\
\qquad[57]\end{array}$ & $\begin{array}{l}\text { Angiogenesis using placental } \\
\text { stem cells }\end{array}$ & $\begin{array}{l}\text { Abbott, S., Edinger, J.W., Francki, } \\
\text { A., Hariri, R.J., Jankovic, V., } \\
\text { Kaplunovsky, A., Labazzo, K., } \\
\text { Law, E., Padliya, N.D., Paredes, J., } \\
\text { Wang, J.L./ Anthrogenesis } \\
\text { Corporation }\end{array}$ & 2011 & $\begin{array}{l}\text { Methods of treating individuals having } \\
\text { diseases or disorders of the circulatory } \\
\text { system, using placental cells }\end{array}$ \\
\hline
\end{tabular}




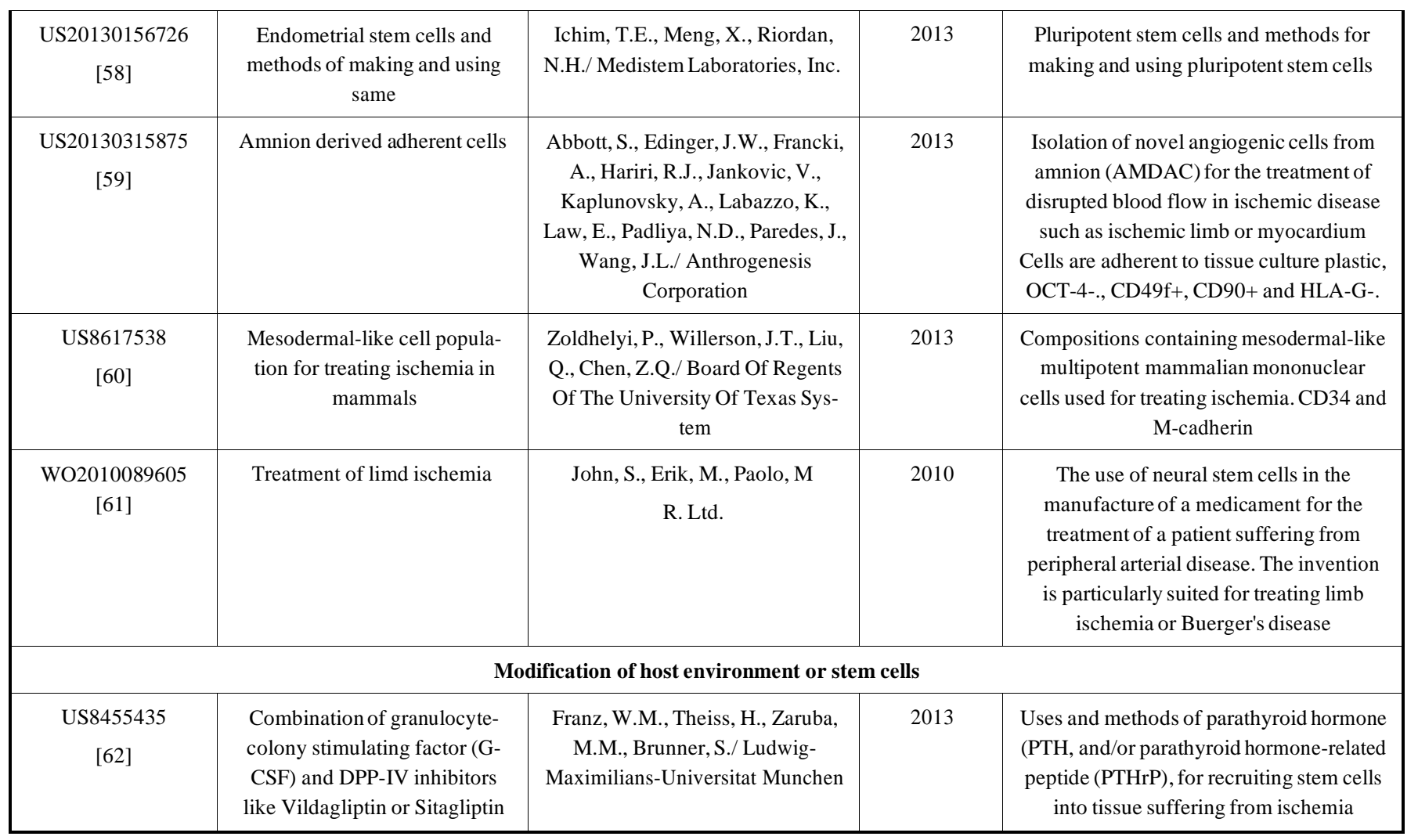

Table (1) contd....

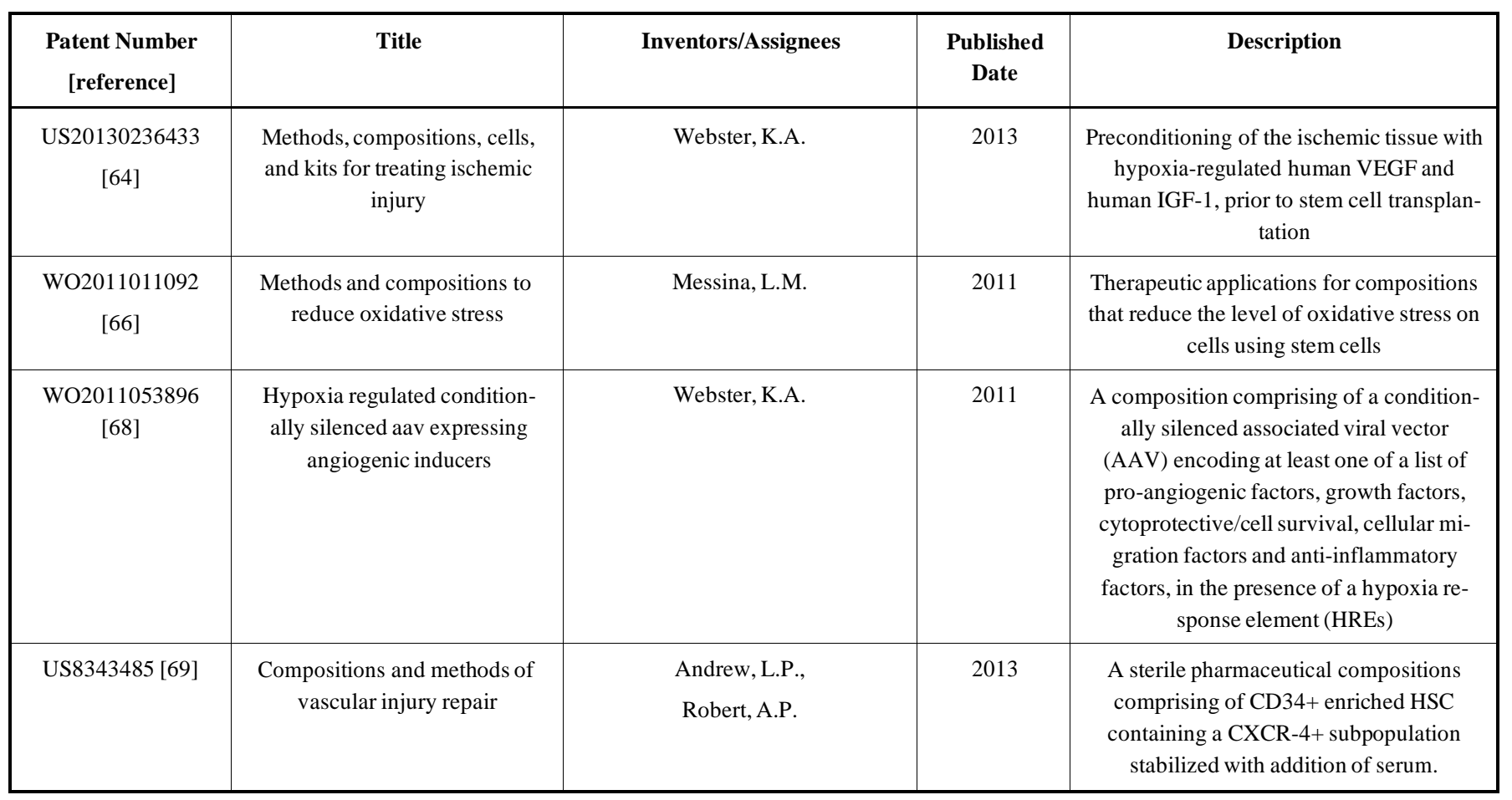

from peripheral blood. The invention provides a pharmaceu- tical composition comprising of CD34+ cells, a plasma pro- tein and an isotonic solution. Methods of obtaining CD34+ cells from a subject are also provided, illustrating all the steps from promoting mobilization of CD34+ cells from bone marrow and collection of the mobilized CD34+ cells from peripheral blood (which optionally involves apheresis). In some embodiments, the method further includes an en- riching step in which CD34+ cells are separated from CD34- by employing specific antibodies or antigen-binding frag- ments. Pharmaceutical compositions described in the patent are to be administered in an amount effective to increase development of blood vessels in the damaged tissue or to repair the tissue in the subject. The pharmaceutical composi- tion comprising the cells is formulated for different types of administration, such as parenteral, subcutaneous, intrave- nous, intramuscular, intra-arterial, intrathecal, or intraperito- neal, via nasal, spray, oral, aerosol, rectal, or vaginal admini- stration. Cells obtained through these methods can also 
be administered via a cell delivery matrix. This patent also cov-ers association of the stem cell population with a second moiety, such as a therapeutic agent or a diagnostic agent.

The invention US20040258670 [54] described in this patent relates to delivering a therapeutic quantity of CD133+/CD34+ enriched human MSCs and/or endothelial generating cells. The patent covers isolation and enrichment of CD133+/CD34+ endothelial precursor cells or MSC pref- erably from umbilical cord blood but also covers isolation from peripheral blood and bone marrow. The preferred use of this invention is to enrich endothelial generating cells prior to administration and expansion in culture. This inven- 
tion is designed to treat ischemic myocardium by increasing blood flow to the ischemic region but also covers treatment of other ischemic tissue for example ischemic limb. Route of administration includes intravenous injection or infusion in close proximity to the ischemic tissue to facilitate migration of the cells to the ischemic tissue such as an intracardiac infusion. The patent also covers genetic manipulation of the enriched endothelial generating cells to additionally express a recombinant polypeptide such as VEGF.

The invention described in the patent EP2428563 [55] relates to methods and compositions for differentiation of Multipotent Adult Progenitor Cells (MAPCs) towards the endothelial lineage with arterial, venous and lymphatic endo- thelial characteristics, this will be beneficial in vivo with the differentiation to vascular cells such as arterial or venous cells. MAPCs are nonembryonic, non-germ and non- embryonic germ cells that can differentiate into ectodermal, endodermal and mesodermal cells types. They are positive for telomerase and Oct-3A (Oct-3/4), and isolated from bone marrow, brain, muscle, placenta, umbilical cord and cord blood, liver, spinal cord, blood or skin. MAPCs can differen- tiate in vivo where they can form vascular cells, such as arte- rial or venous cells. MAPCs are capable of extensive culture without loss of differentiation potential and show efficient, long term, engraftment and differentiation along multiple developmental lineages in vivo without evidence of teratoma formation. MAPCs cultured in the presence of VEGF165 were found to acquire endothelial cell markers, including VEGF-R1 and 2, Tie-1, Tie-2, KDR, Flt-1, CD26, CD105, avp3, CD34, VE-cadherin and von Willebrand Factor. They also had increased expression of markers for arterial (Hey-2, 
Dll-4, EphrinB2 and EphrinB1) and venous (EphB4) endo- thelium, demonstrating the potential for arterial and venous endothelial differentiation of these cells. A subset of the population of differentiated cells expressed smooth muscle actin, a marker of smooth muscle, showing that MAPCs can differentiate into both endothelial cells and smooth muscle cells. Either autologous, allogeneic or xenogeneic cells can be administered to a patient, moreover in undifferentiated, terminally differentiated or in a partially differentiated form, genetically altered or unaltered, by direct introduction to a site of interest, on or around the surface of an acceptable matrix, systemically or in combination with a pharmaceuti- cally acceptable carrier in order to repair, replace or to pro- mote the growth of existing and new blood vessels.

The patent WO2014022373 [56] describes a pharmaceu- tical formulation of MSCs, which can be isolated from autologous and/or heterologous bone marrow and its admini- stration with/without prostacyclin for treating and preventing peripheral arterial disease. This method also includes the use of MPC-derived conditioned culture medium or the MSCs- conditioned culture medium pre-treated with prostacyclin. In some embodiments the formulation also contains endothe- lial precursors cells (EPCs) that are transformed with a nu-cleic acid that increases the expression or biological activity of a protein selected from the following group: endothelial nitric oxide synthase (eNOS), heme oxygenase (HMOX1) and prostacyclin synthase (PTGIS).

The patent US20110250182 [57] provides methods of using PDACs (placenta derived adherent cells), to promote angiogenesis, and to treat diseases or disorders of the circula- tory system (for example Ischemic Diseases) by improving angiogenesis. Disruption of placental tissue using enzymatic digestion or perfusion allows for the isolation of the desired PDACs. Administration of PDACs can be implanted alone or in combination with a matrix by injection, infusion and by delivery via catheter. PDACs could be incubated or cultured in the presence of factors that stimulate stem or progenitor cell differentiation according to a cardiogenic, angiogenic, hemangiogenic, or vasculogenic pathway, such as growth factors, chemokines, cytokines, cellular products, demethy- lating agents, and other factors which are known to stimulate cell trans-differentiation. Inventors report that the control of the trans-differentiation can be assessed by evaluating the expression of at least one of the following markers such as cardiomyosin, skeletal myosin, or GATA4, or by functional parameters as the acquisition of a beating rhythm which can be spontaneous or otherwise induced, or by the ability of cell engraftment into the cardiac muscle of the patient without inducing arrhythmias. The number and type of cells collected from a mammalian placenta can be moni- tored, for example, by measuring changes in morphology and cell surface markers using standard cell detection tech- niques such as flow cytometry, cell sorting, immunocyto- chemistry, fluorescence activated cell sorting (FACS), magnetic activated cell sorting (MACS), by examination of the morphology of cells using light or confocal microscopy, and by measuring changes in gene expression by PCR and gene expression profiling. Different preparation of placen- 
tal cells, obtained from different subjects, can be stored in a dedicated cell bank for long-term storage. PDACs could be genetically engineered to produce recombinant or exogenous cytokines associated with and they can be conditionally im- mortalized by transfection with any suitable vector contain- ing a growth-promoting gene. Kits ready to use for the treatment of MI, provide a therapeutic cell composition comprising of PDACs, which can be prepared in a pharma- ceutically acceptable form, for example by mixing with a carrier, and an applicator. The kits are suitable for the treat- ment of an individual who has a disease or disorder of the circulatory system which would allow this therapy to be used in wider medical centers.

The invention US20130156726 [58] describes the use and isolation of pluripotent stem cells to induce in vitro, ex vivo and in vivo cell trans-differentiation into various cell lineages and to produce conditioned medium. The use of adult stem cells in therapy is limited by their availability, invasiveness of extraction, and in some cases limited prolif- erative capacity, it is also necessary to avoid karyotypic ab- normalities and potential oncogenic transformation during in vitro culture, this patent addresses these critical issues. The invention describes isolated and purification of undifferenti- ated mammalian pluripotent stem cells obtained from endo- metrium, endometrial stroma, endometrial membrane or menstrual blood. These cells retain the ability to differentiate into one or more different cell types and thus offers the op- portunity to treat a range of conditions. The conditioned me- dium can potentially stimulate cell survival and viability, growth, proliferation and differentiation of totipotent, pluri- potent, multipotent or differentiated stem cell. It has also the ability to stimulate and to enhance hematopoiesis and/or to inhibit, reduce and limit inflammation. The patent also de- scribes a kit that can be used to readily access pluripotent stem cells, which would benefit medical centers without spe- cialist stem cell isolation expertise and equipment.

The patent US20130315875 [59] provides novel angio- genic cells isolated from amnion, called "amnion derived adherent cells" (AMDACs). Amnion derived adherent cells are extracted from amnion tissue by enzymatic digestion using one or more tissue-digesting enzymes. The number and type of cells collected from amnion can be monitored, for example, by measuring changes in morphology and cell sur- face markers using standard cell detection techniques such as immunolocalization, flow cytometry, cell sorting, immuno- cytochemistry, fluorescence activated cell sorting (FACS), magnetic activated cell sorting (MACS), by examination of the morphology of cells using light or confocal microscopy, and by measuring changes in gene expression using PCR and gene expression profiling. These techniques can also be used to identify cells that are positive for one or more particular markers. The patent covers: i) differentiation of AMDACs, to exhibit at least one characteristic of an endothelial cell, a myogenic cell, or a pericytic cell; ii) genetic modification of AMDACs, to additionally produce a nucleic acid or polypep- tide of interest directly or to produce a differentiated cell (osteogenic cell, myocytic cell, pericytic cell, or angiogenic cell) that produces a nucleic acid or polypeptide of interest;iii) a range of compositions comprising AMDACs, which can be used in the clinical practice, for instance in pharma- ceutical compositions matrices and scaffolds, and media conditioned by amnion derived adherent cells; iv) Condi- tional immortalization of AMDACs by transfection with any suitable vector containing a growth-promoting gene. The patent suggests that the benefits from these cells can be used in a number of conditions including ischemic disease to in- duce angiogenesis and differentiation into cardiac or endo- thelial cells.

The patent US20110104124 [60] reports various compo- sitions containing an effective amount of mesodermal-like multipotent mammalian mononuclear cells that express both CD34 and M-cadherin cell surface markers. These composi- tions can be used in different embodiments such as prevent- ing, treating or reducing the severity of tissue ischemia or an ischemia associated disorder. The method comprises of iso- lation of cells from autologous/heterologous bone marrow displaying a positive expression for CD34 and M-cadherin (both 95\% of positive surface expression). A minor fraction (10\%) of this population can also express Pax3 or Pax7. Subsequent administering directly to an ischemic tissue siteor an adjacent site, wherein the dose comprises of $10^{2}-10^{10}$

cells bearing both CD34 and M-cadherin cell surface mark- ers. The employment of this cell population may include the in vivo repopulation with new myocytes and vascularization of the ischemic site. By administrating the said cell popula- tion, functional new blood vessels formation can be im-proved, and consequently one or more ischemia symptoms. In addition, the method can comprise the additional admini- stration of angiogenic cytokines to the ischemic or adjacent ischemic tissue, specifically the myocardium or ischemic limb, to provide synergetic benefit.

This patent additionally utilizes the invention as a diag- nostic marker detecting the level and/or distribution of CD34+/Mcadherin+ mesodermal-like precursor cells in a mammalian tissue sample. This enables indication of self- repairing ability. Alternatively, it can be used to measure success of stem cell transplant.

The patent application WO2010089605 [61] describes the use of neural stem cells for the treatment of patients suf- fering from peripheral arterial disease. Neural stem cells offer an alternative to bone marrow derived stem cells pro- viding a scalable, safe and potent allogenic treatment. Neural stem cells are derived from ventricular and hippocampal regions of fetal and adult brain or derived from ESCs which have undergo differentiation to neural stem cells.

The invention US8455435 [62] described in this patent relates to uses and methods of parathyroid hormone (PTH), and parathyroid hormone-related peptide (PTHrP), for re- cruiting stem cells into tissue suffering from ischemia. The patent also covers the use of a combination of G-CSF and a dipeptidyl peptidase IV (DPP IV) inhibitor/antagonist. The DPP IV antagonist/inhibitor can be used in combination with G-CSF or a G-CSF fragment. Additionally the patent relates to a pharmaceutical composition comprising of PTH, and PTHrP and G-CSF, with and without DPP IV inhibitor/antagonist.

As discussed previously the influence of parathyroid hormone on the HSC niche in the bone marrow strengthens survival and self-renewal of hematopoietic stem cells. It is known that PTH has cardiovascular functions such as vaso- dilatation, increased 
myocardial blood flow, hypotensive effects, myocardial hypertrophy, positive chronotropic and contractility effects. PTH has the ability to work with G-CSF in mobilizing circulating progenitor cell numbers and tissue perfusion [34]. Whereas, inhibition of DPP-IV significantly improved cardiac function after MI in a mouse model [63], in correlation with increased mobilization and a higher rate of endothelial cell proliferation. This treatment is useful for the recruiting of stem cells from the bone marrow into the periphery and, further, is useful for the prevention and treat- ment of ischemia.

The invention US20130236433 [64] described in this patent is based on the discovery that stem cells, when in- jected into ischemic tissue of mammals, can be protected by preconditioning of the ischemic tissue with hypoxia- regulated human Vascular endothelial growth factor (VEGF) and human Insulin Growth Factor-1 (IGF-1) [65]. In the pat- ent compositions, cells, kits and methods are reported. They include the use of hypoxia-regulated, inflammation-responsive conditionally-silenced nucleic acids to promote stem cell survival and vascularization in ischemic disease. It was hy-pothesized that tissue engineering with hypoxia-regulated growth and survival factors may reduce toxicity, before stem cell injection, thus promoting cell survival and the efficacy of the therapy. By using such combination of gene and stem cell therapy, it has been proven to improve both cell survival and tissue reperfusion. The invention also describes a typical method of treating tissue already injured or at risk of ischemic injury in a subject. For instance, the administration to the patient of a therapeutically effective amount of a composition which includes at least one nucleic acid encoding at least one cell survival factor for protecting stem and progeni- tor cells from ischemia, and/or alternatively at least one nu- cleic acid operably linked to a hypoxia-regulated promoter and subsequently administration to the subject prior to injection stem and/or progenitor cells.

The invention WO2011011092 [66] is based on the un- derstanding that oxidative stress is a critical factor regulating stem cell function. A physiological balance of the redox state in a cell or a tissue can be achieved by administering a com- position or a combination of agents resulting in reversal or reduction of oxidative cell or tissue injury. These include the administration of one or more activators of an anti-oxidative pathway, co-factors, anti-oxidants or free radical scavengers; for example L-Arginine, $\mathrm{N}$ acetyl-cysteine, and/or L-Cysteine, BH4 (tetrahydrobiopterin) prior to stem cell ther- apy.

The patent, US20130131152 [67], discusses a method relating to the treatment of hypoxia and associated conditions, especially directional angiogenesis for therapeutic ad- vantage. The method uses a conditionally silenced adeno- 
associated vector (AAV) expression system which expresses the desired factor. The method uses a combination of silenc- ers such as NRSE and TOAD/FROG to regulate growth fac-tor expression in hypoxia and ischemic affected tissues to give a more rapid and efficient revascularization and tissue salvage before, during or post injury. This invention can be used to replace the preclinical and gene therapy models fo-cused on angiogenesis which are primitive in comparison due to the inadequate delivery vehicles and constitutively active gene expression that provides non-directional vessel growth.

The AAV gene expression is regulated by the promoter, for example phosphoglycerate kinase (PGK) promoter, in conjunction with a combined cassette of hypoxia response element (HRE) along with the combination of silencer ele- ments, which are activated by ischemic conditions. The ad- ministration of pro-angiogenic growth factor genes such as; endothelial growth factor, fibroblast growth factor (FGF), platelet derived growth factor (PDGF), insulin-like growth factor (IGF), epidermal growth factor (EGF), transforming growth factor (TGF), hepatocyte growth factor (HGF), pro- liferin, angitropin, angiopoietin, vascular endothelial growth factor (VEGF), transforming growth factor beta (TGF-beta) or erythropoietin (EPO) is a possibility. Further examples of factors are c-kit ligand/ stem cell factor, insulin, insulin like growth factor-l (IGF-1), nerve growth factor (NGF), bone morphogenetic protein (BMP), leukemia inhibitory factor (LIF), brain derived neurotrophic factor (BDNF), interleu kins such as but not limited to interleukin 3 (IL-3), interleu- kin 6 (IL-6), interleukin 7 (IL-7), and interleukin 13 (IL-13), stromal derived factor (SDF), stem cell factor (SCF), granu- locyte colony stimulating factor (G-CSF), and matrix metal- loproteinase (MMP) inhibitors.

The conditionally silenced vectors may be used to treat hypoxia associated condition such as MI in order to reduce the severity of cell/tissue damage during the post ischemic period.

The methods outline ways to isolate subpopulations in- cluding but not exclusively adherence to plastic culture dishes followed by culture in a selective medium, separation via specific cell markers whether it be due to their expression or lack of expression, markers such as: CD133, CD45, CD34, CD31, Sca-1, c-kit, Thy1, and CD105. The stem cells used in this invention can be autologous, allogeneic or xeno- genic. The choice of which depends on the urgency of the need for treatment.

The patent, WO2011053896 [68], outlines methods for treating hypoxia and the conditions associated with it by directional angiogenesis/arteriogenesis using conditionally silenced vectors such as adeno-associated virus (AAV) or lentiviral vector, which express the required factor for direc- tional angiogenic manipulation. The system will transport the desired genes to target cells such as skeletal and cardiac myocytes, endothelial cells, smooth muscle cells, pericytes and stem cells. Different stem cells can be used such as mus- cle, cardiac, mesenchymal, hematopoietic or endothelial pro-genitor stem cells. The patent describes the purification,ex vivo culture, and transfection/infection with conditionally silenced vectors.

This invention is potentially important for the treatment of ischemic diseases and conditions, where new vessel growth is vital for the repair and recovery of affected cells, tissues and microenvironments. The treatment relies upon hypoxic conditions to regulate the AAV vector through a silencer element, which includes but is not limited to NRSE and TOAD/FROG in a heterogeneous combination, which are activated in ischemic conditions while inhibited during aerobic conditions. The vector also depends upon promoters such as phosphoglycerate kinase (PGK) to regulate pro- angiogenic gene expression alongside hypoxia response ele- ments (HREs), inflammatory response elements (IREs) or shear-stress activated elements (SSAEs). The treatment can be used in concert with a specific drug regime such as vaso- dilators (adenosine, nitric oxide donors such as prostagland- ins or antioxidants), to have additional benefits.

Current therapeutic methods to induce angiogenesis have flaws in their methods; for example, inadequate delivery vehicles that extinguished gene expression too early and the delivery is unregulated so genes do not provide the direc- tional cues needed for the correct new vessel growth. This invention could be the answer to deliver a more efficient and robust therapeutic cue to regulate angiogenesis.

\section{METHODS AND DIAGNOSTIC}

The patent US8343485 [69, 70] provides to a sterile pharmaceutical formulation composed of an enriched CD34+ population that contains a subpopulation of CD34+/CXCR-4 cells holding a CXCR-4-mediated chemotactic activity, the methods of preparation and its use for the treatment of vas- cular-injury repair, including MI. Moreover, the pharmaceu- tical composition contains a stabilizing amount of serum that is characterized as having the said properties for at least 24 hours after that acquisition of the chemotactic hematopoietic stem cell product, when tested in vitro after passage through a catheter.

The chemotactic hematopoietic stem cell factor is prepared by isolating and purifying CD34+ hematopoietic stem cells from a population of mononuclear cells isolated from autolo- gous bone marrow and peripheral blood after treatment with a hematopoietic stem cell mobilizing agent (such as G-CSF, GM-CSF or a pharmaceutical acceptable analog or derivate).

The chemotactic hematopoietic stem cell factor contains varying proportions of pure CD34+ cells. The sterile composi- tion patented is formulated for parentheral administration in coronary blood vessel, in myocardium, artery, vein or muscle and it can contain one of the compatible active agent (hema- topoietic stem cell mobilizing agent), such as angiotensin- converting enzyme inhibitor, beta-blocker, a diuretic, anti- arrhythmic agent, anti-anginal agent, anticoagulant, vasoactive agent, fibrinolytic agent, or hypercholesteromic agent.

The sterility of the chemotactic hematopoietic cell prod- uct is confirmed by a multi-step procedure patented in this protocol. 



\section{Table (2) contd....}

\section{CURRENT \& FUTURE DEVELOPMENTS}

Reviewing clinical trials offers an informative method to establish the potential, validity, progress and success of claims put forward in patents involving medical innovations. Unlike documentation available for patents it is relatively difficult to accurately establish the exact number of worldwide clinical trials currently taking place in any particular field. There are different publically available open databases on clinical trials where information can be sourced; however the data does not always match between databases. Nevertheless, these data- bases provide a good reflection of the current trends in the usage of this technology. The United States National Institute of Health Clinical Trial database (ClinicalTrials.gov [71]) cur- rently provide >1765 open records of worldwide trials involv- ing stem cells. Within that group, 53 trials are currently re- cruiting patients for stem cells trials involving MI, whereas 27 stated PAD or critical limb ischemia as the target condition

Table 2. Within the UK there are currently 41 clinical trials ongoing involving stem cells, cardiovascular is the second most common target disease with oncology leading the way (Sourced from Cell Therapy Catapult UK Clinical Trial Data- base [72]). Five of the current trials involving stem cells in- clude MI while one is investigating PAD.

Clinical trial SRCTN65630838, is a prospective, double- blind randomized trial that will enrich bone marrow derived cells using CD133+ selection and test this in patients under- going coronary surgery. This clinical trial appears to be us- ing the invention described in patent US20040258670. Autologous CD133+ stem cells will be transplanted into scarred areas to induce angiogenesis and neomyogenesis. The clinical endpoint will assess left ventricular thickening by MRI, 6 months after injection. Secondary outcome meas- urements include left ventricular function, scarring, troponin I levels and quality of life scores.

Table 2. Ongoing Clinical Trials for Treatment of Myocardial Infarction and Peripheral Artery Disease.

\begin{tabular}{|c|c|c|c|}
\hline NCT Number & Title & $\begin{array}{c}\text { Sponsor/Collaborators } \\
\text { Phase }\end{array}$ & Primary/Secondary Outcome Measures \\
\hline NCT00350766 & Cell therapy in myocardial infarction & $\begin{array}{c}\text { Ministry of health, Brazil } \\
\text { Phase } 3\end{array}$ & $\begin{array}{l}\text { Global left ventricular ejection fraction change. death. } \\
\text { Acute myocardial infarction, stroke and hospital } \\
\text { admission due to cardiovascular cause }\end{array}$ \\
\hline NCT00725738 & $\begin{array}{l}\text { Intracoronary autologous stem cell trans- } \\
\text { plantation in ST elevation myocardial } \\
\text { infarction: Tracia study }\end{array}$ & $\begin{array}{c}\text { National Heart Institute, } \\
\text { Mexico|National Center of } \\
\text { Blood Transfusion Mexico. } \\
\text { Phase 2/3 }\end{array}$ & $\begin{array}{l}\text { Evaluate the mean LVEF increase by magnetic resonance } \\
\text { imaging (MRI) at } 6 \text { months of follow up between the stem } \\
\text { cell group and the control group }\end{array}$ \\
\hline NCT01625949 & $\begin{array}{c}\text { Stem cell therapy in patients with myocar- } \\
\text { dial infarction and persistent total occlusion } \\
\text { of infarct related artery }\end{array}$ & $\begin{array}{l}\text { All India institute of medical } \\
\text { sciences, New Delhi }\end{array}$ & Left ventricular function \\
\hline NCT00275977 & $\begin{array}{l}\text { Treatment of myocardial infarction with } \\
\text { bone marrow derived stem cells }\end{array}$ & $\begin{array}{c}\text { Odense University Hospital } \\
\text { Phase } 1\end{array}$ & $\begin{array}{c}\text { Safety } \\
\text { Change in left ventricular funtion at } 4 \text { months followup } \\
\text { using contrast enhanced echocardiography }\end{array}$ \\
\hline NCT01652209 & $\begin{array}{l}\text { Relief(A randomized, open labeled, multi- } \\
\text { center trial for safety and efficacy of intra- } \\
\text { coronary adult human mesenchymal stem } \\
\text { cells acute myocardial in Farction) }\end{array}$ & $\begin{array}{l}\text { Pharmicell Co., Ltd. } \\
\text { Phase } 3\end{array}$ & Left ventrical function by MRI \\
\hline NCT01536106 & $\begin{array}{l}\text { Rapid delivery of autologous bone marrow } \\
\text { derived stem cells in acute myocardial } \\
\text { infarction patients. }\end{array}$ & $\begin{array}{c}\text { Totipotent RX cell therapy Pvt. } \\
\text { Ltd.|TotipotentRX Corpo- } \\
\text { ration } \\
\text { Phase } 1 / \text { Phase } 2\end{array}$ & $\begin{array}{l}\text { Number of adverse events as a measure of safety. Changes } \\
\text { in the global left ventricular ejection fraction(LVEF), LV } \\
\text { volumes-end systolic volume (ESV) and end diastolic vol- } \\
\text { ume (EDV), infarct size, myocardial mass, myocardial } \\
\text { viability and regional wall motion abnormalities. Major } \\
\text { adverse cardiac events (MACE)/Quality of life }\end{array}$ \\
\hline NCT00501917 & MAGIC cell-5-combicytokine trial & $\begin{array}{l}\text { Seoul National University } \\
\text { Hospital } \\
\text { Phase 2/Phase } 3\end{array}$ & $\begin{array}{c}\text { Change of left ventricular ejection fraction measured by } \\
\text { cardiac MRI } \\
\text { Wall motion score index exercise capacity BNP }\end{array}$ \\
\hline NCT00437710 & $\begin{array}{l}\text { Safety and efficacy of bone marrow cell } \\
\text { transplantation in humans myocardial } \\
\text { infarction }\end{array}$ & $\begin{array}{l}\text { Azienda Uniṫ̂̂E Sanitaria } \\
\text { Locale di Piacenza } \\
\text { Phase } 1 / \text { Phase } 2\end{array}$ & $\begin{array}{l}\text { Mortality and morbidity. left ventricular function and re- } \\
\text { modeling, baroreflex sensitivity, stress induced myocardial } \\
\text { ischemia }\end{array}$ \\
\hline
\end{tabular}




\begin{tabular}{|c|c|c|c|}
\hline NCT Number & Title & $\begin{array}{c}\text { Sponsor/Collaborators } \\
\text { Phase }\end{array}$ & Primary/Secondary Outcome Measures \\
\hline NCT00529932 & $\begin{array}{l}\text { A trial using CD133 enriched bone marrow } \\
\text { cells following primary angioplasty for } \\
\text { acute myocardial infarction }\end{array}$ & $\begin{array}{l}\text { Onze Lieve Vrouw Hospi- } \\
\text { tal|King's College London }\end{array}$ & $\begin{array}{l}\text { Comparison of changes in myocardial thickening in non- } \\
\text { viable akinetic / hypokinetic LV wall segments as deter- } \\
\text { mined by cardiac magnetic resonance imaging (cMRI) in } \\
\text { treated and control groups }\end{array}$ \\
\hline NCT01781390 & $\begin{array}{l}\text { Safety study of allogeneic mesenchymal } \\
\text { precursor cell infusion in myocardial in- } \\
\text { farction }\end{array}$ & $\begin{array}{l}\text { Angioblast Sys- } \\
\text { tems|Mesoblast, } \\
\text { Inc.|Mesoblast, Ltd.|Teva } \\
\text { Pharmaceuticals USA } \\
\text { Phase } 2\end{array}$ & $\begin{array}{l}\text { Frequency of the total major adverse cardiac and cere- } \\
\text { brovascular events (MACCE) }\end{array}$ \\
\hline NCT01974128 & $\begin{array}{c}\text { Study to assess the safety and cardiovascu- } \\
\text { lar effects of autologous adipose-derived } \\
\text { stromal cells implantation in patients during } \\
\text { the acute recovery phase of st-elevation } \\
\text { myocardial infarction }\end{array}$ & $\begin{array}{l}\text { Ageless Regenerative Institu- } \\
\text { te/Instituto de Medicina Rege- } \\
\text { nerativa, S.A. de C.V. } \\
\text { Phase 1/Phase } 2\end{array}$ & $\begin{array}{l}\text { Cardiac improvement } \\
\text { primary safety objective }\end{array}$ \\
\hline NCT01394432 & $\begin{array}{l}\text { Estimation study for endocardial mesen- } \\
\text { chymal stem cells implantation in patients } \\
\text { after acute myocardial infarction }\end{array}$ & $\begin{array}{l}\text { Meshalkin research institute of } \\
\text { pathology of circulation } \\
\text { Phase } 3\end{array}$ & $\begin{array}{l}\text { Reduction in left ventricle systolic volume on } 15 \% \text { mesured } \\
\text { by MRI/All-cause death|number of patients with throm- } \\
\text { boembolic events|number of heart failure hospitaliza- } \\
\text { tions/Distance during 6-minute walking test }\end{array}$ \\
\hline NCT01454323 & $\begin{array}{c}\text { Intracoronary infusion of bone marrow } \\
\text { mononuclear cells in patients with previous } \\
\text { myocardial infarction }\end{array}$ & $\begin{array}{c}\text { Fundaciì n PÌYblica Andaluza } \\
\text { Progresoy Salud } \\
\text { Phase } 2\end{array}$ & $\begin{array}{l}\text { Change from baseline in left ventricular ejection fraction } \\
\text { (LVEF), major adverse cardiac events (MACE), functional } \\
\text { grade of the new york heart association (NYHA) }\end{array}$ \\
\hline NCT00711542 & $\begin{array}{l}\text { Effects of intracoronary progenitor cell } \\
\text { therapy on coronary flow reserve after } \\
\text { acute MI }\end{array}$ & $\begin{array}{l}\text { Johann wolfgang goethe } \\
\text { University Hospi- } \\
\text { tals/University of Leipzig } \\
\text { Phase 1/Phase } 2\end{array}$ & $\begin{array}{l}\text { Improvement of coronary flow reserve in the infarct vessel, } \\
\text { Improvement of relative coronary flow reserve, Improve- } \\
\text { ment of global and regional left ventricular ejection fraction } \\
\text { Major adverse cardiac events (death, MI, rehospitalization } \\
\text { for heart failure, revascularization). }\end{array}$ \\
\hline NCT01753440 & $\begin{array}{l}\text { Allogeneic stem cells implantation com- } \\
\text { bined with coronary bypass grafting in } \\
\text { patients with ischemic cardiomyopathy }\end{array}$ & $\begin{array}{l}\text { AHEPA University Hospital } \\
\text { Phase 2/Phase } 3\end{array}$ & $\begin{array}{l}\text { Left ventricular ejection fraction. Myocardial segmental } \\
\text { perfusion } \\
\text { All-cause mortality and all-cause morbidity. } \\
\text { Major adverse cardiac and cerebrovascular events }\end{array}$ \\
\hline NCT01758406 & $\begin{array}{l}\text { Transplantation of autologous cardiac stem } \\
\text { cells in ischemic heart failure }\end{array}$ & $\begin{array}{c}\text { Royan Institute } \\
\text { Phase } 2\end{array}$ & $\begin{array}{l}\text { Death, arrhythmia, hospitalization, ejection fraction. Pro } \\
\text { BNP changes. NYHA functional class }\end{array}$ \\
\hline
\end{tabular}




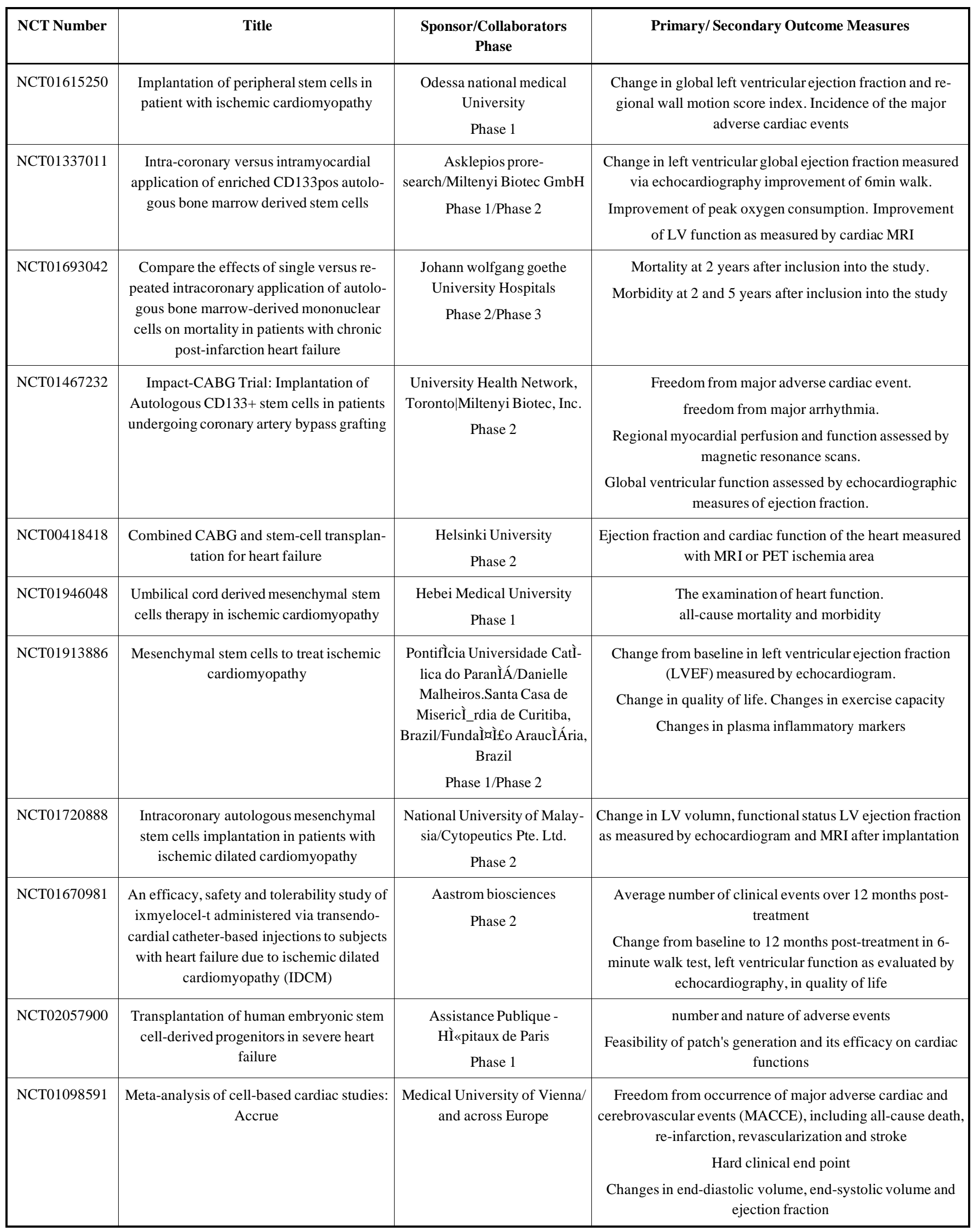




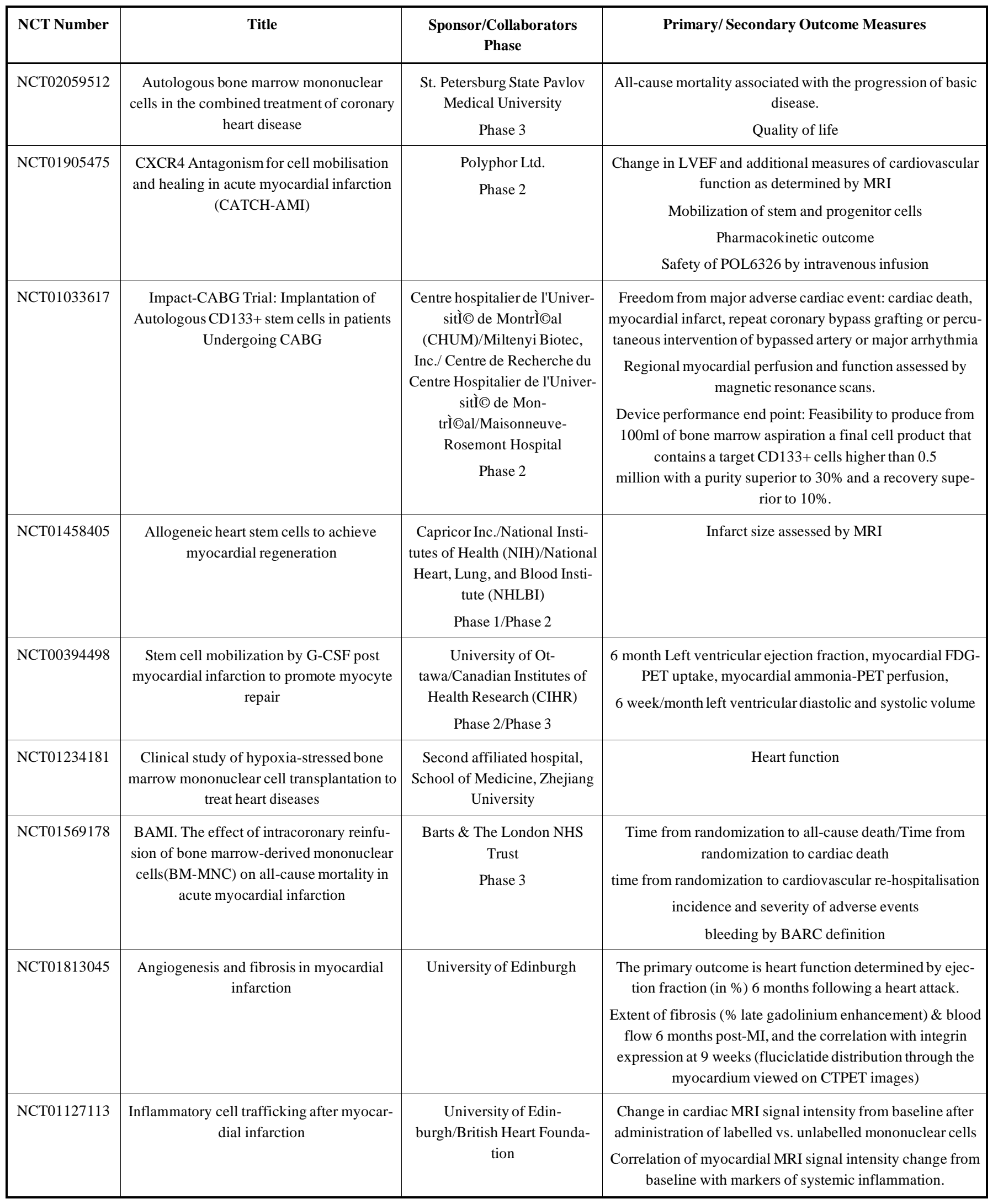




\begin{tabular}{|c|c|c|c|}
\hline NCT Number & Title & $\begin{array}{c}\text { Sponsor/Collaborators } \\
\text { Phase }\end{array}$ & Primary/Secondary Outcome Measures \\
\hline NCT02052427 & $\begin{array}{l}\text { Safety \& efficacy of adipose-derived regen- } \\
\text { erative cells in the treatment of chronic } \\
\text { myocardial ischemia (ATHENA II) }\end{array}$ & $\begin{array}{c}\text { Cytori therapeutics } \\
\text { Phase } 2\end{array}$ & $\begin{array}{l}\text { Primary efficacy - Change in minnesota living with heart } \\
\text { failure questionnaire } \\
\text { Secondary efficacy - change in } \mathrm{mVO}_{2} \text {. Change in } \\
\text { LVESV/LVEDV, Ejection Fraction, perfusion defect, heart } \\
\text { failure symptoms, angina, and quality of life. }\end{array}$ \\
\hline NCT00984178 & $\begin{array}{l}\text { Trial of hematopoietic stem cells in acute } \\
\text { myocardial infarction }\end{array}$ & $\begin{array}{l}\text { Tecam Group|Hospital Gen- } \\
\text { eral Universitario Gregorio } \\
\text { Maraìon } \\
\text { Phase } 2\end{array}$ & $\begin{array}{l}\text { The change in left ventricular ejection fraction and left } \\
\text { ventricular end-systolic volume relative to baseline meas- } \\
\text { ured by magnetic resonance } \\
\text { The change in left ventricle end-diastolic volume, segment } \\
\text { contractility, wall thickness and intravascular ultrasound } \\
\text { reendothelization relative to baseline measured by magnetic } \\
\text { resonance and other imaging techniques } \\
\text { To determine the safety of the study procedures }\end{array}$ \\
\hline NCT01770613 & $\begin{array}{l}\text { A study of allogeneic mesenchymal bone } \\
\text { marrow cells in subjects with st segment } \\
\text { elevation myocardial infarction (STEMI) }\end{array}$ & $\begin{array}{c}\text { Stemedica cell technologies, } \\
\text { Inc./Mercy gilbert medical } \\
\text { center at AZ/Chandler regional } \\
\text { medical center at chandler } \\
\text { AZ/University of California, } \\
\text { San Diego } \\
\text { Phase } 2\end{array}$ & $\begin{array}{l}\text { The safety and tolerability of a MBMC intravenous admini- } \\
\text { stration during the twelve month study period as determined } \\
\text { by major adverse events MACE endpoint.| } \\
\text { LV end diastolic and systolic volume } \\
\text { Infarct size measured by MRI, with and without contrast } \\
\text { (only for patients eligible for MRI } \\
\text { Global left ventricular ejection fraction (measured by } \\
\text { echocardiography }\end{array}$ \\
\hline \multicolumn{4}{|c|}{ Peripheral artery disease } \\
\hline NCT01456819 & $\begin{array}{l}\text { Intramuscular mononuclear cells and mes- } \\
\text { enchymal stem cells transplantation to treat } \\
\text { chronic critical limb ischemia }\end{array}$ & $\begin{array}{l}\text { National University of Malay- } \\
\text { sia/Cytopeutics Pte. Ltd. } \\
\text { Phase } 2\end{array}$ & $\begin{array}{l}\text { Change in angiogenesis } \\
\text { Change in blood supply } \\
\text { Change in ulcer size } \\
\text { Visual Analog Score } \\
\text { Exercise Treadmill Test }\end{array}$ \\
\hline NCT02099500 & $\begin{array}{l}\text { Autologous adipose-derived stromal cell } \\
\text { delivered via intramuscular injections for } \\
\text { the treatment of critical limb ischemia }\end{array}$ & $\begin{array}{c}\text { Ageless regenerative institute } \\
\text { Phase 1/Phase } 2\end{array}$ & $\begin{array}{l}\text { Improvement from baseline in perfusion as measured by } \\
\text { ankle-brachial index and collateral artery number/ } \\
\text { Number of adverse events reported } \\
\text { Improvement from baseline in improvement or resolution of } \\
\text { ulcer or gangrene } \\
\text { Limb Salvage }\end{array}$ \\
\hline NCT01867190 & $\begin{array}{l}\text { Study to assess efficacy and safety of bone } \\
\text { marrow derived stem cells in patients with } \\
\text { critical limb ischemia }\end{array}$ & $\begin{array}{l}\text { Lifecells, LLC. } \\
\text { Phase 1/Phase } 2\end{array}$ & $\begin{array}{l}\text { To assess the efficacy and safety of intra-arterial infusion } \\
\text { and intramuscular injection of ASCT } 01 \text { on the combined } \\
\text { primary endpoint of major amputation (above the ankle) or } \\
\text { persisting critical limb ischemia (no clinical or perfusion } \\
\text { improvement) }\end{array}$ \\
\hline
\end{tabular}


Table (2) contd....

\begin{tabular}{|c|c|c|c|}
\hline NCT Number & Title & $\begin{array}{c}\text { Sponsor/Collaborators } \\
\text { Phase }\end{array}$ & Primary/Secondary Outcome Measures \\
\hline NCT02145897 & $\begin{array}{l}\text { To evaluate the safety and efficacy of IM } \\
\text { and IV administration of autologous } \\
\text { ADMSCs for treatment of CLI }\end{array}$ & $\begin{array}{l}\text { Kasiak Research Pvt. Ltd. } \\
\text { Phase 1/Phase } 2\end{array}$ & $\begin{array}{l}\text { To assess the safety } \\
\text { To assess the efficacy }\end{array}$ \\
\hline NCT01408381 & $\begin{array}{l}\text { Intra-arterial infusion of autologous bone } \\
\text { marrow mononuclear cells in non-diabetic } \\
\text { patients with critical limb ischemia }\end{array}$ & $\begin{array}{c}\text { Fundaciìn PÌ } 1 \text { blica Andaluza } \\
\text { Progresoy Salud/Iniciativa } \\
\text { Andaluza en terapias Avanza- } \\
\text { das } \\
\text { Phase } 2\end{array}$ & $\begin{array}{c}\text { Adverse events } \\
\text { Ankle-brachial index } \\
\text { Transcutaneous oxygen pressure }\left(\mathrm{TcO}_{2}\right) / \text { Greater ulcer size } \\
\text { Degree of rutherford-becker } \\
\text { Perimeter calf muscle } \\
\text { faster opacity in infra-popliteal vessels at } 6 \text { months com- } \\
\text { pared with the basal situation of the patient }\end{array}$ \\
\hline NCT00488020 & Stem cells for treating critical ischemia & $\begin{array}{l}\text { Instituto de Molestias Cardio- } \\
\text { vasculares } \\
\text { Phase } 1\end{array}$ & $\begin{array}{l}\text { Suppress pain and heal ischemic ulcers/improve quality of } \\
\text { life }\end{array}$ \\
\hline NCT01049919 & $\begin{array}{c}\text { Safety and efficacy study of autologous } \\
\text { concentrated bone marrow aspirate (cBMA) } \\
\text { for Critical Limb Ischemia (CLI) }\end{array}$ & $\begin{array}{l}\text { Biomet, Inc./Biomet Biol- } \\
\text { ogics, LLC }\end{array}$ & $\begin{array}{l}\text { Time to treatment failure/Perfusion and quality of life meas- } \\
\text { urements }\end{array}$ \\
\hline NCT01351610 & $\begin{array}{l}\text { Tolerability and Efficacy of Intravenous } \\
\text { Infusion of Autologous MSC_Apceth for } \\
\text { the Treatment of Critical Limb Ischemia }\end{array}$ & $\begin{array}{l}\text { Apceth GmbH \& Co. KG } \\
\text { Phase 1/Phase }\end{array}$ & $\begin{array}{c}\text { Collection of adverse events } \\
\text { Safety laboratory values } \\
\text { ECG findings } \\
\text { Analysis of inflammation markers } \\
\text { Comparison of course of haemodynamic and vascular } \\
\text { processes }\end{array}$ \\
\hline NCT00922389 & $\begin{array}{l}\text { A clinical trial on diabetic foot using pe- } \\
\text { ripheral blood derived stem cells for Treat- } \\
\text { ing Critical Limb Ischemia }\end{array}$ & $\begin{array}{l}\text { Beike Biotech India Pvt.ltd } \\
\text { Phase 1/Phase } 2\end{array}$ & $\begin{array}{c}\text { Adverse events and laboratory parameters } \\
\text { Trans cutaneous partial pressure of Oxygen: } \mathrm{TCpO}_{2}\end{array}$ \\
\hline
\end{tabular}




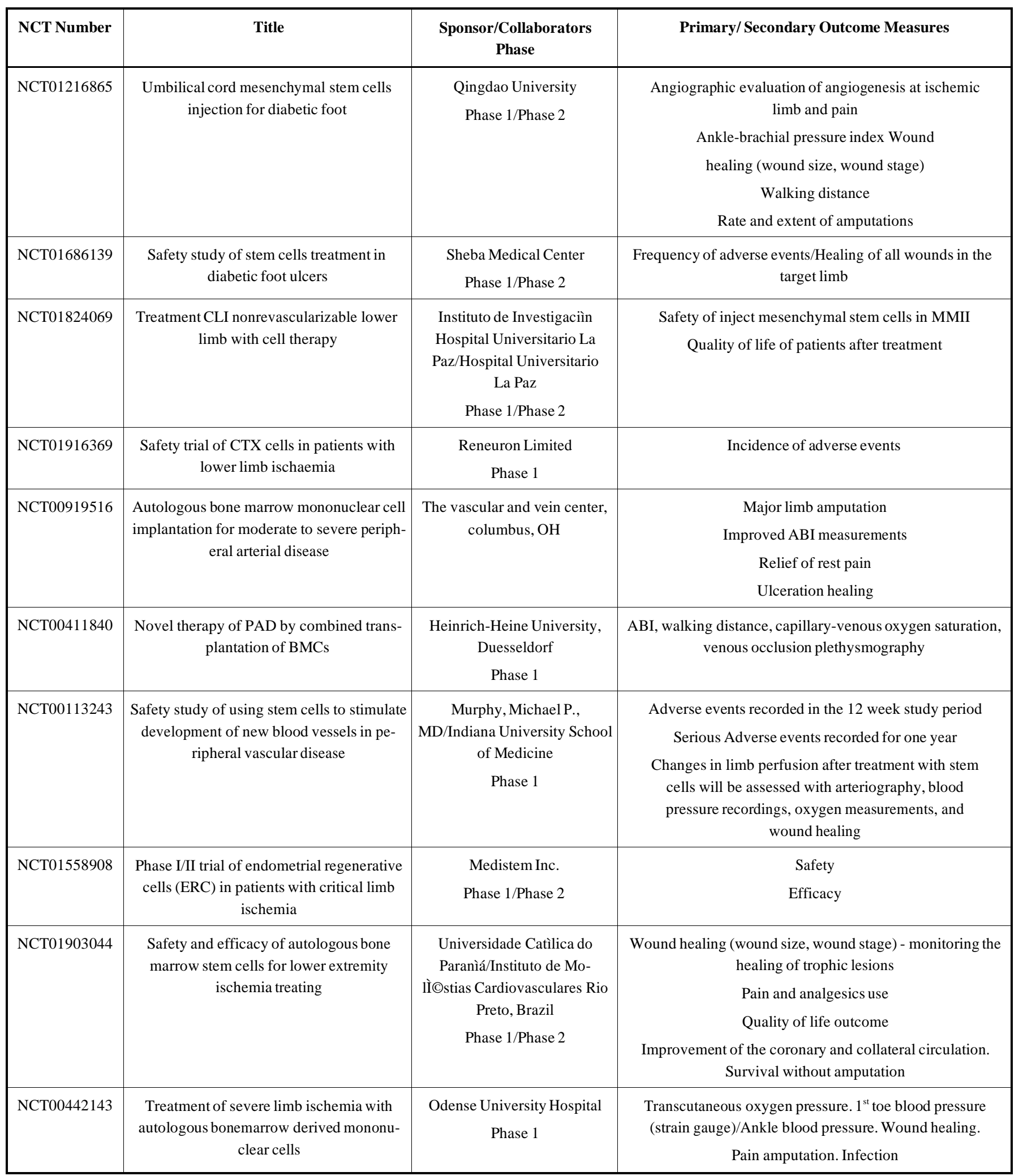

Clinical trial number NCT00747708, is a randomized trial investigating the co-administration of bone marrow pro- genitor cells with Granulocyte colony-stimulating factor (G-CSF) in patients with left ventricular dysfunction secondary to ischemic heart disease. The study has three arms; Arm 1, patients will receive G-CSF or placebo peripheral injection. Arm 2, percutaneous intracoronary injection of G-CSF fol- lowed by BM progenitor cells or placebo. Arm 3, percutaneous intracoronary injection of G-CSF followed by intramyo- cardial injection of BM progenitor cells or placebo. G-CSF is widely used in bone marrow transplantation to induce hema- topoietic stem cell mobilization, more recently G-CSF was observed to influence stromal cell-derived factor 1 (SDF-1) and its receptor CXCR4 levels, increasing homing of trans- planted cells and reducing apoptosis of 
cardiomyocytes [73-

76].

An interesting clinical trial is currently investigating the effectiveness of rapid stem cell therapy in MI. NCT00765453 is a Phase 2 trial aiming to assess if myocardium can be recovered by combining stem cell therapy with primary angioplasty. BMMNC will be administered within 5 hours of a MI at the same time as primary angioplasty. Primary outcome will be assessed by longitudinal change in LV ejection fraction over 1 year.

Clinical trial NCT01569178 and 2006-000280-28 are both assessing safety of stem cells administration.

Clinical trial 2006-000280-28, will deliver bone marrow mononuclear cells via intracoronary injection in patients with dilated cardiomyopathy secondary to myocardial ischemia. Its aim is to demonstrate that a single intracoronary infusion of autologous bone marrow-derived mononuclear cells is safe and reduces all-cause mortality in patients.

Clinical trial 2006-000280-28, is a Phase I/II safety toler- ability test administering a dose escalation of adult haema- topoietic stem cells to patients with established myocardial ischemia.

Clinical trial NCT01916369 sponsored by ReNeuron is currently recruiting in the UK focusing on PAD. It is a Phase I dose safety study of intramuscular administration of CTX0E03 which is a neural stem cell line. The primary objective is to assess the safety of increasing doses of CTX0E03 in addition to tolerability of intramuscular injec- tion. This trial to be conducted in patients with PAD is re- lated to the patent WO2010089605, which describes the in- vention of CTX0E03 for PAD treatment.

Clinical trial NCT01558908 by Medistem Inc. are utiliz- ing endometrial regenerative cells in patients with critical limb ischemia. This promising use of endometrial-derived cells is being fully utilized in heart failure. Currently endo- metrial regenerative cells are in Phase II clinical trials for congestive heart failure [74]. Regenerative cells from the endometrium are reported to be superior to other sources of regenerative cells as they have greater expansion capability [74]. Bearing in mind that endogenous growth factors reside in the endometrium and this is an organ with great angio-genic potential. These clinical trials are probably utilizing patent US20130315875 [59] describing the use of novel angiogenic cells isolated from amnion, called "amnion derived adherent cells" (AMDACs)

\section{CONCLUSION}

Similar to industrial revolution which saw a steep rise in patent applications the advent of potential far-reaching technologies brings forward today's prospectors and pioneers driving substantial increase in patent submission laying claim to their invention. So, it is no surprise that the explosion in stem cell publications has led to a rapid and sustained growth in patent submissions in regenerative medicine. Applications range from sourcing new stem cell populations from different tissue or providing selection criteria. These patents are currently being vigorously tested in clinical trials for safety and efficacy, in the hope that real breakthroughs can be made. Investigations are now focusing on how to im- prove patency of stem cells and include methods modifying the microenvironment, timing of stem cell treatment and genetic makeup of the stem cells themselves. With the sheer number of patents and scientists focusing on this field that even if a small proportion of these patents can be realized it is great hope this would lead to unlimited benefit for ischemic cardiovascular disease.

\section{CONFLICT OF INTEREST}

The authors confirm that this article content has no con- flict of interest.

\section{ACKNOWLEDGEMENTS}

Colin E. Murdoch and Elena De Falco designed the concept, wrote and revised the manuscript. Milda Bartkeviciute, Sophie A.B.-S, Camilla Siciliano and Roberta Altobelli gathered and analysed the patents. CEM is funded by Framework 7 Marie Sklodowska-Curie International Incoming Fellowship [PIIF-GA-2013-626633]. The Authors thank Fondazione Roma.

\section{LIST OF ABBREVIATIONS}

\begin{tabular}{|c|c|c|c|c|c|}
\hline MI & $=$ & Myocardial infarct & & & \\
\hline PAD & $=$ & Peripheral artery disease HSCs & $=$ & Hematopoietic & stem cells PTH \\
\hline \multicolumn{6}{|c|}{ Parathyroid Hormone } \\
\hline PTHrP & $=$ & Parathyroid Hormone-Related & Peptide G-CSF & $=$ & Granulocyte Colony Stimulating Factor DPP \\
\hline IV & $=$ & Dipeptidyl Peptidase IV & & & \\
\hline HSCs & $=$ & Hematopoietic Stem Cells & & & \\
\hline IGF-1 & $=$ & Insulin Growth Factor-1 & & & \\
\hline VEGF & $=$ & Vascular Endothelial Growth I & Factor & & \\
\hline EPCs & $=$ & Endothelial Progenitor Cells & & & \\
\hline
\end{tabular}


Prostacyclin Synthase

$\begin{array}{ll}\text { HMOX1 } & =\text { Heme Oxygenase } \\ \text { eNOS } & =\text { Endothelial Nitric Oxide Synthase } \\ \text { PAH } & =\text { Pulmonary Arterial Hypertension } \\ \text { PVD } & =\text { Peripheral Vascular Disease } \\ \text { CLI } & =\text { Critical Limb Ischemia } \\ \text { PDACs } & =\text { Placenta Derived Adherent Cells MACS } \\ \text { AMDACs } & =\text { Amnion Derived Adherent Cells } \\ \text { BH4 } & =\text { Tetrahydrobiopterin } \\ \text { G-CSF } & =\text { Granulocyte Colony-Stimulating Factor } \\ \text { PDACs } & =\text { Placenta Derived Adherent Cells }\end{array}$

\section{REFERENCES}

[1] Nerem RM. Regenerative medicine: The emergence of an industry. JR Soc Interface 2010; (7 Suppl 6): S771-5.

[2] Espacenet worldwide patent search available at www.epo.org n.d. (Accessed on: August 27, 2014).

[3] Smolina K, Wright FL, Rayner M. Determinants of the decline in mortality from acute myocardial infarction in England between 2002 and 2010: Linked national database study 2012; 8059: 1-9.

[4] Fowkes FGR, Rudan D, Rudan I, Aboyans V, Denenberg JO, McDermott MM, et al. Comparison of global estimates of prevalence and risk factors for peripheral artery disease in 2000 and 2010: A systematic review and analysis. Lancet 2013; 382: 132940 .

[5] Tendera M, Aboyans V, Bartelink M-L, Baumgartner I, Clément D, Collet J-P, et al. ESC Guidelines on the diagnosis and treatment of peripheral artery diseases: Document covering atherosclerotic disease of extracranial carotid and vertebral, mesenteric, renal, upper and lower extremity arteries: The task force on the diagnosis and treatment. Eur Heart J 2011; 32: 2851-906.

[6] Marrett E, DiBonaventura M daCosta, Zhang Q. Burden of peripheral arterial disease in Europe and the United States: A patient survey. Health Qual Life Outcomes 2013; 11:175.

[7] Botham CM, Bennett WL, Cooke JP. Clinical trials of adult stem cell therapy for peripheral artery disease. Methodist Debakey Cardiovasc J 2013; 9: 201-5.

[8] Itzhaki-Alfia A, Leor J, Raanani E, Sternik L, Spiegelstein D, Netser S, et al. Patient characteristics and cell source determine the number of isolated human cardiac progenitor cells. Circulation 2009; 120: 2559-66.

Hristov M, Erl W, Weber PC. Endothelial progenitor cells: Mobilization, differentiation, and homing. Arterioscler Thromb Vasc Biol 2003; 23: 1185-9.

[10] Zhang L, Xu Q. Stem/Progenitor cells in vascular regeneration. Arterioscler Thromb Vasc Biol 2014; 34: 1114-9.

[11] Shantsila E, Watson T, Lip GYH. Endothelial progenitor cells in cardiovascular disorders. J Am Coll Cardiol 2007; 49: 741-52.

[12] Wollert KC, Drexler H. Clinical applications of stem cells for the heart. Circ Res 2005; 96: 151-63.

[13] Goumans M-J, Maring JA, Smits AM. A straightforward guide to the basic science behind cardiovascular cell-based therapies. Heart 2014; 100: 1153-7.

[14] Bergmann O, Bhardwaj RD, Bernard S, Zdunek S, Barnabé-Heider $\mathrm{F}$, Walsh S, et al. Evidence for cardiomyocyte renewal in humans. Science 2009; 324: 98-102.

[15] Beltrami AP, Barlucchi L, Torella D, Baker M, Limana F, Chimenti S, et al. Adult cardiac stem cells are multipotent and support myocardial regeneration. Cell 2003; 114: 763-76.

[16] Mirotsou M, Jayawardena TM, Schmeckpeper J, Gnecchi M, Dzau VJ. Paracrine mechanisms of stem cell reparative and regenerative actions in the heart. J Mol Cell Cardiol 2011; 50: 280-9.

[17] Torsney E, Xu Q. Resident vascular progenitor cells. J Mol Cell
Cardiol 2011; 50: 304-11.

[18] Tang Z, Wang A, Yuan F, Yan Z, Liu B, Chu JS, et al. Differentiation of multipotent vascular stem cells contributes to vascular diseases. Nat Commun 2012; 3: 875.

[19] Chong JJH, Yang X, Don CW, Minami E, Liu Y-W, Weyers JJ, et al. Human embryonic-stem-cell-derived cardiomyocytes regenerate non-human primate hearts. Nature 2014; 510: 273-7.

[20] Yoshida Y, Yamanaka S. iPS cells: A source of cardiac regeneration. J Mol Cell Cardiol 2011; 50: 327-32.

[21] Orlic D, Kajstura J, Chimenti S, Bodine DM, Leri A, Anversa P. Bone marrow stem cells regenerate infarcted myocardium. Pediatr Transplant 2003; 7 (Suppl 3): 86-8.

[22] Timmers L, Lim SK, Hoefer IE, Arslan F, Lai RC, van Oorschot $\mathrm{AM}$, et al. Human mesenchymal stem cell-conditioned medium improves cardiac function following myocardial infarction. Stem Cell Res 2011;6: 206-14.

[23] Smits AM, van Laake LW, den Ouden K, Schreurs C, Szuhai K, van Echteld CJ, et al. Human cardiomyocyte progenitor cell transplantation preserves long-term function of the infarcted mouse myocardium. Cardiovasc Res 2009; 83: 527-35.

[24] Bolli R, Tang X-L, Sanganalmath SK, Rimoldi O, Mosna F, AbdelLatif A, et al. Intracoronary delivery of autologous cardiac stem cells improves cardiac function in a porcine model of chronic ischemic cardiomyopathy. Circulation 2013; 128: 122-31.

[25] Ratcliffe E, Glen KE, Naing MW, Williams DJ. Current status and perspectives on stem cell-based therapies undergoing clinical trials for regenerative medicine: Case studies. Br Med Bull 2013; 108: 73-94.

[26] Franchi F, Ezenekwe A, Wellkamp L, Peterson KM, Lerman A, Rodriguez-Porcel M. Renin inhibition improves the survival of mesenchymal stromal cells in a mouse model of myocardial infarction. J Cardiovasc Transl Res 2014: 7(6): 560-9.

[27] Androutsellis-Theotokis A, Leker RR, Soldner F, Hoeppner DJ, Ravin R, Poser SW, et al. Notch signalling regulates stem cell numbers in vitro and in vivo. Nature 2006; 442: 823-6.

[28] Wang N, Xu Y, Qin T, Wang F-P, Ma L-L, Luo X-G, et al. Myocardin-related transcription factor-A is a key regulator in retinoic acid-induced neural-like differentiation of adult bone marrow-derived mesenchymal stem cells. Gene 2013; 523: 178-86.

[29] Zhang LX, DeNicola M, Qin X, Du J, Ma J, Zhao TY, et al. Specific Inhibition of HDAC4 in cardiac progenitor cells enhances myocardial repairs. Am J Physiol Cell Physiol 2014; 307(4): C35872.

[30] Zhang Z, Liang D, Gao X, Zhao C, Qin X, Xu Y, et al. Selective inhibition of inositol hexakisphosphate kinases (IP6Ks) enhances mesenchymal stem cell engraftment and improves therapeutic efficacy for myocardial infarction. Basic Res Cardiol 2014; 109(4): 417.

[31] Asahara T. Isolation of putative progenitor endothelial cells for angiogenesis. Science 1997; 275: 964-6.

[32] Hamano K, Li TS, Kobayashi T, Tanaka N, Kobayashi S, Matsuzaki $\mathrm{M}$, et al. The induction of angiogenesis by the implantation of autologous bone marrow cells: A novel and simple 
therapeutic method. Surgery 2001; 130: 44-54.

[33] Kinnaird T, Stabile E, Burnett MS, Lee CW, Barr S, Fuchs S, et al. Marrow-derived stromal cells express genes encoding a broad spectrum of arteriogenic cytokines and promote in vitro and in vivo arteriogenesis through paracrine mechanisms. Circ Res 2004; 94: 678-85.

[34] Napoli C, William-Ignarro S, Byrns R, Balestrieri ML, Crimi E, Farzati B, et al. Therapeutic targeting of the stem cell niche in experimental hindlimb ischemia. Nat Clin Pract Cardiovasc Med 2008; 5: 571-9.

[35] Zaruba M-M, Huber BC, Brunner S, Deindl E, David R, Fischer R, et al. Parathyroid hormone treatment after myocardial infarction promotes cardiac repair by enhanced neovascularization and cell survival. Cardiovasc Res 2008; 77: 722-31.

[39] Katare R, Stroemer P, Hicks C, Stevanato L, Patel S, Corteling R, et al. Clinical-grade human neural stem cells promote reparative neovascularization in mouse models of hindlimb ischemia. Arterioscler Thromb Vasc Biol 2014; 34: 408-18.

[40] Napoli C, Williams-Ignarro S, de Nigris F, de Rosa G, Lerman LO, Farzati B, et al. Beneficial effects of concurrent autologous bone marrow cell therapy and metabolic intervention in ischemiainduced angiogenesis in the mouse hindlimb. Proc Natl Acad Sci USA 2005; 102: 17202-6.

[41] Murdoch CE, Chaubey S, Zeng L, Yu B, Ivetic A, Walker SJ, et al. Endothelial NADPH oxidase-2 promotes interstitial cardiac fibrosis and diastolic dysfunction through pro-inflammatory effects and endothelial-mesenchymal transition. J Am Coll Cardiol 2014; 63(24): 2734-41.

[42] Murdoch CE, Grieve DJ, Cave AC, Looi YH, Shah AM. NADPH oxidase and heart failure. Curr Opin Pharmacol 2006; 6: 148-53.

[43] Ray R, Murdoch CE, Wang M, Santos CX, Zhang M, Alom-Ruiz $\mathrm{S}$, et al. Endothelial Nox4 NADPH oxidase enhances vasodilatation and reduces blood pressure in vivo. Arterioscler Thromb Vasc Biol 2011; 31: 1368-76.

[44] Pimentel D, Haeussler DJ, Matsui R, Burgoyne JR, Cohen RA, Bachschmid MM. Regulation of cell physiology and pathology by protein S-glutathionylation: Lessons learned from the cardiovascular system. Antioxid Redox Signal 2012; 16: 524-42.

[45] Liang R, Ghaffari S. Stem cells, redox signaling, and stem cell aging. Antioxid Redox Signal 2014; 20: 1902-16.

[46] Jang Y, Sharkis SJ. Stem cells in hematology. A low level of reactive oxygen species selects for primitive hematopoietic stem cells that may reside in the low-oxygenic niche $2007 ; 110$ : 305663.

[47] Tesio M, Golan K, Corso S, Giordano S, Schajnovitz A, Vagima Y, et al. Enhanced c-Met activity promotes G-CSF-induced mobilization of hematopoietic progenitor cells via ROS signaling. Blood 2011; 117: 419-28.

[48] Urao N, Ushio-Fukai M. Redox regulation of stem/progenitor cells and bone marrow niche. Free Radic Biol Med 2013: 54: 26-39.

[49] Barbash IM, Chouraqui P, Baron J, Feinberg MS, Etzion S, Tessone A, et al. Systemic delivery of bone marrow-derived mesenchymal stem cells to the infarcted myocardium: Feasibility, cell migration, and body distribution. Circulation 2003; 108: 863-8.

[50] Sherman W, Martens TP, Viles-Gonzalez JF, Siminiak T. Catheterbased delivery of cells to the heart. Nat Clin Pract Cardiovasc Med 2006; 3 (Suppl 1): S57-64

[51] Dixon JA, Gorman RC, Stroud RE, Bouges S, Hirotsugu H, Gorman $\mathrm{JH}$, et al. Mesenchymal cell transplantation and myocardial remodeling after myocardial infarction. Circulation 2009; 120: S220-9.

[52] Tang YL, Tang Y, Zhang YC, Qian K, Shen L, Phillips MI. Improved graft mesenchymal stem cell survival in ischemic heart with a hypoxia-regulated heme oxygenase-1 vector. J Am Coll Cardiol 2005; 46: 1339-50.

[53] Palmer, L., Motlagh, D., Cohen, A., Amrani, D.L. Pharmaceutical composition comprising CD34+ cells. WO2013126590 (2013).

[54] Laughlin, M., Haynesworth, S., Pompili, V. Introducing enriched human endothelial generating cells and mesenchymal stem cells; enhancing vasculogenesis and collateralization around blocked and/or narrowed vessels. US20040258670 (2004).

[55] Prosper, F., Verfaillie, C.M., Lopez-Aranguren, X., Claver, C.C., Luttun, A. Vascular/lymphatic endothelial cells. EP2428563
[36] Yamahara K, Sone M, Itoh H, Yamashita JK, Yurugi-Kobayashi T, Homma K, et al. Augmentation of neovascularization [corrected] in hindlimb ischemia by combined transplantation of human embryonic stem cells-derived endothelial and mural cells. PLoS One 2008; 3: e1666.

[37] Lee EJ, Park H-W, Jeon H-J, Kim H-S, Chang M-S. Potentiated therapeutic angiogenesis by primed human mesenchymal stem cells in a mouse model of hindlimb ischemia. Regen Med 2013; 8: 28393.

[38] Stroemer P, Patel S, Hope A, Oliveira C, Pollock K, Sinden J. The neural stem cell line CTX0E03 promotes behavioral recovery and endogenous neurogenesis after experimental stroke in a dosedependent fashion. Neurorehabil Neural Repair 2009; 23: 895-909.

(2012)

Jeffs, R., Petersen, T., Ilagan, R.M., Wade, M. Treatment of pulmonary arterial hypertension with mesenchymal stem cells. WO2014022373 (2014)

[57] Abbot, S., Edinger, J.W., Francki, A., Hariri, R.J., Jankovic, V., Kaplunovsky, A., Kristen, L., Eric, L., Neerav, D., Padliya, J.P., Jia-Lun, Wang. Angiogenesis using placental stem cells. US20110250182 (2011).

[58] Ichim, T.E., Meng, X., Riordan, N.H. Endometrial stem cells and methods of making and using same. US20130156726 (2013).

[59] Edinger, W., Kaplunovsky, A., Labazzo, K., Padliya, N., Hill. C. Amnion derived adherent cells. US20130315875 (2013).

[60] Zoldhelyi, P.H., Willerson, J.T., Liu, Q., Chen, Z.-Q. Mesodermallike cell population for treating ischemia in mammals. US8617538 (2013).

[61] Sinden, J., Miljan, E., Madeddu, P. Treatment of limb ischemia. WO2010089605 (2010).

[62] Franz, W.M., Theiss, H., Zaruba, M.M., Brunner, S. Combination of granulocyte-colony stimulating factor (G-CSF) and DPP-IV inhibitors like Vildagliptin or Sitagliptin. US8455435 (2013).

[63] Zaruba M-M, Theiss HD, Vallaster M, Mehl U, Brunner S, David $\mathrm{R}$, et al. Synergy between CD26/DPP-IV inhibition and G-CSF improves cardiac function after acute myocardial infarction. Cell Stem Cell 2009; 4: 313-23.

[64] Webster, K.A. Methods, compositions, cells, and kits for treating ischemic injury. US20130236433 (2013).

[65] Herrmann J, Abarbanell A. Optimizing stem cell function for the treatment of ischemic heart disease. J Surg 2011; 166: 138-45.

[66] Messina, L.M. Methods and compositions to reduce oxidative stress. WO2011011092 (2011).

[67] Webster, K.A., Biscayne, K. Hypoxia regulated conditionally silenced AAV expressing angiogenic inducers. US20130131152 (2013).

[68] Webster, K.A. Hypoxia regulated conditionally silenced aav expressing angiogenic inducers. WO2011053896 (2011).

[69] Andrew, L.P., Robert, A.P. Compositions and methods of vascular injury repair. US8343485 (2005).

[70] Webster, K.A. Methods, compositions, cells, and kits for treating ischemic injury. WO2012064920 (2012).

[71] Clinical trial database avaliable at $\mathrm{http}: / /$ clinicaltrials.gov/ct2/search (Accessed on: August 27, 2014).

[72] Catapult cell therapy clinical trial database at https://ct.catapult.org.uk/clinical-trials-database n.d. (Accessed on: August 27, 2014).

[73] Yu J, Hu K, Smuga-Otto K, Tian S, Stewart R, Slukvin II, et al. Human induced pluripotent stem cells free of vector and transgene sequences. Science 2009; 324: 797-801

[74] Bockeria L, Bogin V, Bockeria O, Le T, Alekyan T, Woods E, Brown AA, Ichim T and Patel A. Endometrial regenerative cells for treatment of heart failure: A new stem cell enters the clinic. J of Trans Med 2013. 11: 56

[75] Shim W, Mehta A, Lim SY, Zhang G, Lim CH, Chua T, et al. GCSF for stem cell therapy in acute myocardial infarction: Friend or foe? Cardiovasc Res 2011; 89: 20-30.

[76] Petit I, Szyper-Kravitz M, Nagler A, Lahav M, Peled A, Habler L, et al. G-CSF inG-CSF induces stem cell mobilization by decreasing bone marrow SDF-1 and up-regulating CXCR4. Nat Immunol 2002; 3: 687-94.

[77] Pubmed search engine at www.ncbi.nlm.nih.gov/pubmed/ n.d. (Accessed on: August 27, 2014). 